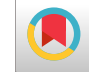

\title{
Prevalence of Depression in Iranian College Students: A Systematic Review and Meta-analysis
}

\author{
Zahra Jaafari ${ }^{1}$, Akram Farhadi (iD) ${ }^{2}$, Faramarz Amin Lari ${ }^{3}$, Fatemeh Sadat Mousavi ${ }^{4}$, Hadis Moltafet ${ }^{4}$, \\ Elaheh Dashti ${ }^{4}$ and Maryam Marzban (iD) ${ }^{2, *}$ \\ ${ }^{1}$ Department of Biostatistics and Epidemiology School of Public Health, Kerman University of Medical Sciences, Kerman, Iran \\ ${ }^{2}$ The Persian Gulf Tropical Medicine Research Center, the Persian Gulf Biomedical Sciences Research Institute, Bushehr University of Medical Sciences, Bushehr, Iran \\ ${ }^{3}$ Department of English Language, School of Paramedical Sciences, Shiraz University of Medical Sciences, Shiraz, Iran \\ ${ }^{4}$ Department of Public Health, Bushehr University of Medical Sciences, Bushehr, Iran \\ "Corresponding author: The Persian Gulf Tropical Medicine Research Center, the Persian Gulf Biomedical Sciences Research Institute, Bushehr University of Medical Sciences, \\ Bushehr, Iran. Email: marzbanh@gmail.com
}

Received 2020 February 17; Revised 2020 August 07; Accepted 2021 January 02.

\begin{abstract}
Context: Depression is a common problem in students. The current study aimed to determine the prevalence of depression in Iranian college students.

Evidence Acquisition: The study was conducted using preferred reporting items for systematic reviews and meta-analysis (PRISMA). We searched both international (i.e. PubMed, Scopus, Science Direct, Web of Science, Embase, and Google Scholar) and national (i.e. SID, Magiran, Iranmedex, and IranDoc) databases from 1991 to June 2019 to identify relevant studies. Cochran's Q test, $\mathrm{I}^{2}$ index, and $\tau^{2}$ index were used to assess the heterogeneity. A random-effects model was employed to combine the results using comparative meta-analysis software version 2.2.

Results: Overall, 89 studies dealing with a total of 33,564 Iranian students were included. The prevalence of depression was estimated at 48.0\% [95\% confidence interval (CI): 43.6 - 52.5\%]. The prevalence of depression was 51.3\% (95\% CI: 41.1 - 61.4\%) and 48.9\% (95\% CI: $41.0-54.8 \%$ ) in males and females, respectively. The prevalence of mild, moderate, and severe depression was estimated at $26.1 \%$ (95\% CI: 23.8 - 28.6\%), 15.5\% (95\% CI:13.1-18.3\%), and 6.4\% (95\% CI: 5.1 - 8\%), respectively. The Beck-I Questionnaire and the GHQ-28 Questionnaire indicated the highest and the lowest prevalence of depression [68.4\% (95\% CI: 38.8 - 88.1\%) vs. 39.2\% (95\% CI: 24.6 - 56.1\%)], respectively. It was proved that the prevalence of depression among Iranian college students has significantly increased during the study period $(\mathrm{P}<0.001)$. Interest in the field was significantly correlated with depression $(\mathrm{P}<0.001)$.

Conclusions: Given the high prevalence of depression among Iranian college students, prevention and treatment programs are strongly recommended.
\end{abstract}

Keywords: Depression, Mental Disorders, Students, Meta-analysis, Iran

\section{Context}

Depression is one of the most common psychiatric disorders (1). According to the global burden of disease (2017), globally, more than 264 million people suffer from depression. Besides, it is estimated that it accounts for about $44,000,000$ years lived with disability (YLDs). According to this study, compared to 2007, the YLD of depression has increased by $14.3 \%$ (2). Everyone is at risk of depression, but some are more vulnerable because of a variety of factors ranging from living conditions to genetic factors (3). Particular risk factors for depression include stressful life events (4), genetics (5), adverse childhood incidents (6), disability, new illness, poor health status, prior depression, bereavement, and sleep disturbance (7). Depressive symp- toms are more prevalent among college students than the general population, and Iranian college students are not an exception; meta-analyses and systematic reviews have estimated a prevalence of 33\% [95\% confidence interval (CI): $32-34 \%]$ for depressive symptoms among Iranian college students (8). Some of the symptoms of the condition include sadness, hopelessness, nervousness, anxiety, and boredom (9).

A wide range of causes, both environmental and personal, can account for this noticeable prevalence. Less close contact with parents or intimate friends, inadequate facilities, and the challenges of adjusting to the new environment (e.g. those associated with living in the dormitory) are examples of environmental causes of depression. Problems related to individual factors include the stress 
associated with the need to make high achievements, uncertainties about the future, lack of interest in the field of study, genetics, family history, gender, socio-economic status (SES), nutritional habits, and risky behaviors (e.g. drug abuse, alcoholism, smoking) (10-12).

\section{Objectives}

The prevalence of depression seems to be increasing among students (13). According to a report, the prevalence of depression among Iranian college students did not increase between 1995 and 2012. However, numerous studies have dealt with the subject since then, a fact that implies the importance of the issue (8). One shortcoming with this report, however, is that some predictive factors of depression have not been considered, nor has the evaluation method of depressive disorders, as an important factor that may affect measuring this phenomenon (8). In addition, comparing the results of this study with the current one, which has been conducted after six years, would provide useful information.

Although a growing number of studies have investigated the prevalence of depression among university students, little is known about its overall country-wide prevalence. In summary, the current study aimed to, firstly, investigate the prevalence of depression among Iranian college students, and secondly, discussing some risk factors related to depression (e.g. age, gender, and marital status). Besides, there is evidence that some factors like living in the dormitory are likely to promote depressive disorder. Moreover, in the present study, the methodology used to measure the severity of depression disorder (which has a key role in detecting depression), the severity of depression, university category (a potential factor that is rarely considered by previous studies), and level of interest in the field of study were all taken into account. Hence, we performed a meta-analysis in order to bring together the factors that potentially affect the prevalence of depression among Iranian university students with the aim of providing useful information for developing future research priorities.

\subsection{Data Sources}

The present study contained several stages including precise problem definition, collection, analysis, and interpretation of the results, and reporting a guide for systematic review and meta-analysis (PRISMA) (14). In order to avoid potential biases, search steps, selection of studies, quality assessment, and data extraction were performed by two independent researchers (J.Z and M.F). In case of a disagreement, a consensus was reached through discussion or, if necessary, the third reviewer was consulted (MM).The final decision was reached following a group discussion.

\section{Evidence Acquisition}

\subsection{Information Sources and Search Strategy}

We systematically searched international [i.e. PubMed, Scopus, Science Direct, Web of Science (ISI), Embase, and Google Scholar] and national [i.e. Scientific Information Database (SID), Magiran, Iranmedex, and Iranian Research Institute for Information Science, and Technology (IranDoc)] databases for the period of 1991 to 2019 in order to identify relevant studies. In order to increase the comprehensiveness of the search, medical subject headings (MeSH) terms and their Persian equivalents were used. The search strategies were ("Depression" [Title/Abstract] OR "Depressive Symptoms" [Title/Abstract] OR "Mental health" [Title/Abstract] OR "Mental disorder" [Title/Abstract] OR "Risk factor" [Title/Abstract] OR "Students" [Title/Abstract]) AND ("Prevalence" [Title/Abstract] OR "Epidemiology" [Title/Abstract]) AND ("Iran" [Title/Abstract/Affiliation]). We also hand-searched the reference list of the selected articles in order to increase the chance of finding potentially relevant studies related to the topic under scrutiny. All eligible articles were included in the systematic review.

\subsection{Inclusion and Exclusion Criteria}

The inclusion criteria were developed based on (evidence-based medicine) the PICO (15), which included: (1) P, quantitative cross-sectional studies on the depression of Iranian college students; (2) I, instruments used in the measurement of depression, which included questionnaires Beck Depression Inventory [Beck (II)], Beck Depression Inventory [Beck (I)], General Health Questionnaire (GHQ-28), Symptom Checklist 90-Revised (SCL-90$\mathrm{R})$, and depression anxiety stress scale (DASS-21); (3) C, comparative groups based on gender, marital status and university type; and (4) O, studies that estimated the Prevalence of depression in Iranian college students.

Exclusion criteria included repetitive articles, irrelevant articles, having a design other than non-crosssectional, inaccessibility of the full text of the study, not investigating a sample of students, studies published before 1991, not reporting the prevalence of depression and its related factors (e.g. studies that only have reported prevalence depression), studied with a poor design, studies that have used rare data collection tools (e.g. Znug's self-rating depression scale (Zung), which was used in 3 articles, depression anxiety stress scales (DASS-42), which was used in 1 article, university student depression inventory (USDI), which was used in 1 article, Ahwaz depression inventory (ADI), which was used in 1 article, Mood and Anxiety Symptom questionnaire, which was used in 2 articles, Symptom Checklist-25 (SCL-25), which was used in 1 article, Tehran multidimensional perfectionism scale (TMPS), which was 
used in 1 article, the cognition checklist, Middlesex Hospital questionnaire, which was used in 3 articles, Hopkins symptom checklist, which was used in 1 article, Hamilton questionnaire, which was used in 2 articles, and studies that have used Beck's Questionnaire without mentioning its type (i.e. type 1 or 2 ) (Figure 1 ).

\subsection{Study Selection}

A total of 2,468 articles were identified, of which 1,088 were excluded. Of the remaining 1,380 articles, 225 articles proved eligible. Following an evaluation of the quality of the latter articles, 89 entered the meta-analysis. Figure 1 illustrates the selection process using the PRISMA flow diagram, which consists of four main stages: identification, screening, eligibility, and inclusion (14).

\subsection{Quality Assessment}

The Newcastle-Ottawa scale (NOS) checklist (16) was used to evaluate the quality of identified studies. NOS contains three sections with the following contents: (1) study selection (four items), (2) comparability (one item), and (3) outcome (two items). Studies with a score of NOS $\geq 7$ are of high quality; $5<$ score $<6$ are of moderate quality, and those with a score of NOS $<5$ (which were excluded) are of poor quality. In this study, two authors (J.Z and M.F) reviewed the full text of identified articles. In case of a disagreement, a consensus was reached through discussion or, if necessary, the third reviewer was consulted (MM). Articles with a low score quality, based on the NOS checklist, were excluded.

\subsection{Data Extraction}

A checklist was developed for data extraction, which included items on the first author, year of publication, implementation year, type of study, study design, sample size, location of study, type of university [university of medical sciences (which are under the authority of the Ministry of Health); public universities (which are affiliated to the Ministry of Science Technology and Research and are financially supported by the government); Islamic Azad University (a non-governmental university that is privately run on student tuition fees); Payame Noor University (a semi-private university, a public university where the training is semi-private)], method of measuring depression, the prevalence of depression, mean and standard deviation of age, and some other depression-related factors. The extracted information was independently reviewed by two researchers (M.H and D.E). In cases of ambiguity, the authors of the articles were contacted.

\subsection{Statistical Analysis}

The binomial distribution was used to calculate the variance of each study. To assess the heterogeneity of identified studies, Cochran's $\mathrm{Q}$ test, $\mathrm{I}^{2}$, and $\tau^{2}$ statistics were used. Due to the heterogeneity of the studies, a randomeffects model was used to estimate the prevalence of depression $(17,18)$. Sensitivity analysis was conducted to investigate the effect of excluding one study on the overall estimate at a time (19). In order to identify the cause of heterogeneity of prevalence of depression, sub-group analysis of depression was performed based on gender, level of depression, type of applied questionnaires, and the type of university. In addition, the meta-regression model was used to investigate the prevalence of depression based on the year of study. Moreover, publication bias was assessed by Begg's test. All the analyses were performed using the comprehensive meta-analysis (CMA) version 2.2 software while adopting a significance level of $<0.05$.

\section{Results}

\subsection{Characteristics of Eligible Studies}

A total of 89 articles was included, with a total of 33,564 Iranian college students were eligible for the review. The mean age of subjects investigated in 60 studies (for which information were available) was 21.84 years (95\% CI: 21.60 $22.08 \%$ ). The characteristics of eligible studies are provided in Table 1.

\subsection{Total Prevalence of Depression}

The overall pooled crude prevalence, which was defined as the event rate of depressed people to the total sample of studies on university students, was estimated as 48.0\% (95\% CI: 43.6 - 52.5\%), and the heterogeneity $\left(\mathrm{I}^{2}\right)$ was 98.08\% ( $\mathrm{P}<0.001$ and $\left.\tau^{2}=0.731\right)$, (Figure 2 ). According to the sensitivity analysis for the prevalence of depression, after removing a study at a time, the results were still robust (Figure 3).

\subsection{Subgroup Analysis Based on Gender}

Prevalence of depression among males and females was 51.3\% (95\% CI: $41.1-61.4 \%$ ) and 48.9\% (95\% CI: 41.0 $54.8 \%$ ), respectively. The results of the subgroup analysis revealed no significant difference between males and females concerning the prevalence of depression $(\mathrm{P}=0.589)$ (Table 2). 


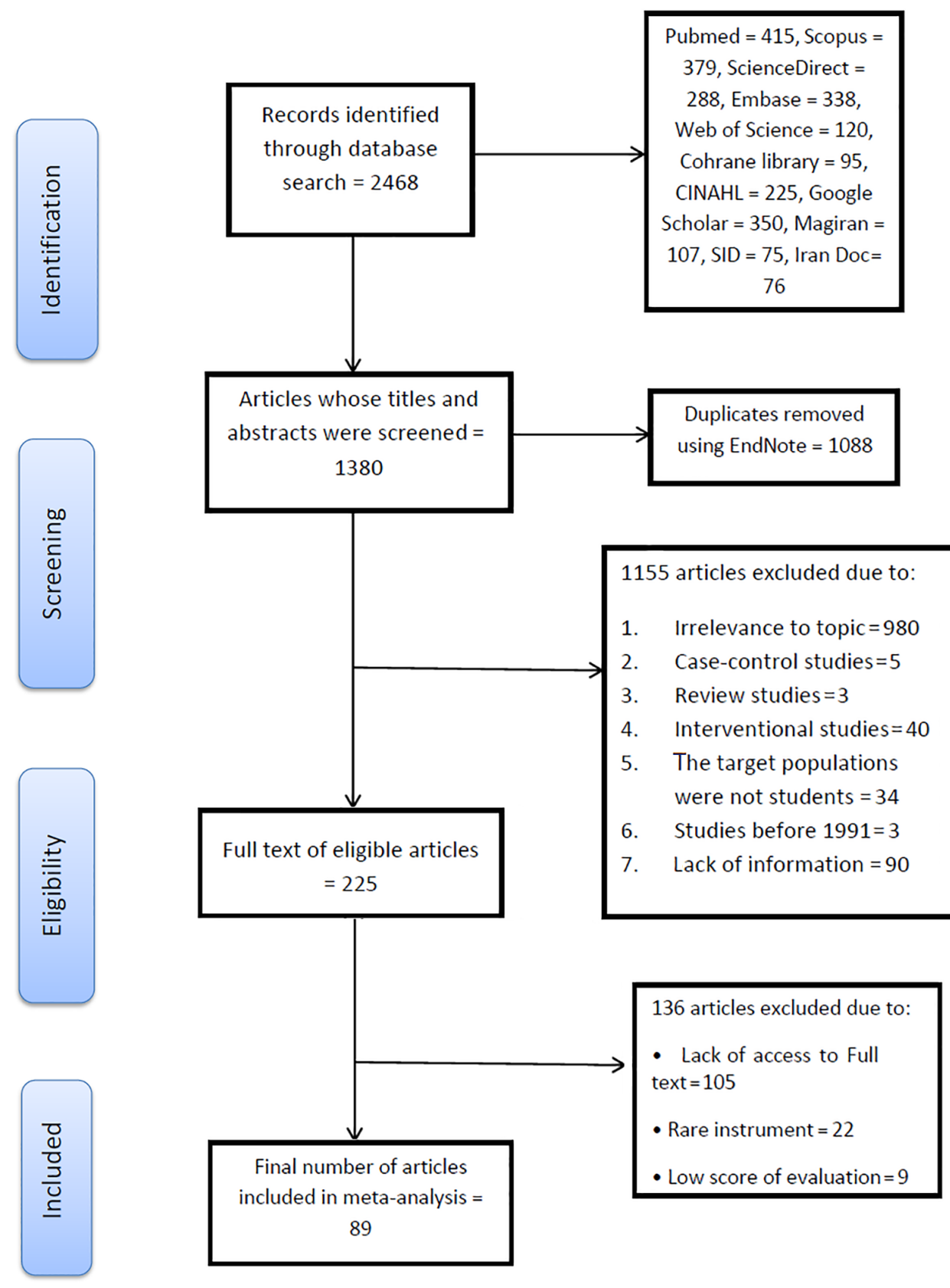

Figure 1. The flow diagram indicating study selection 
Meta-Analysis

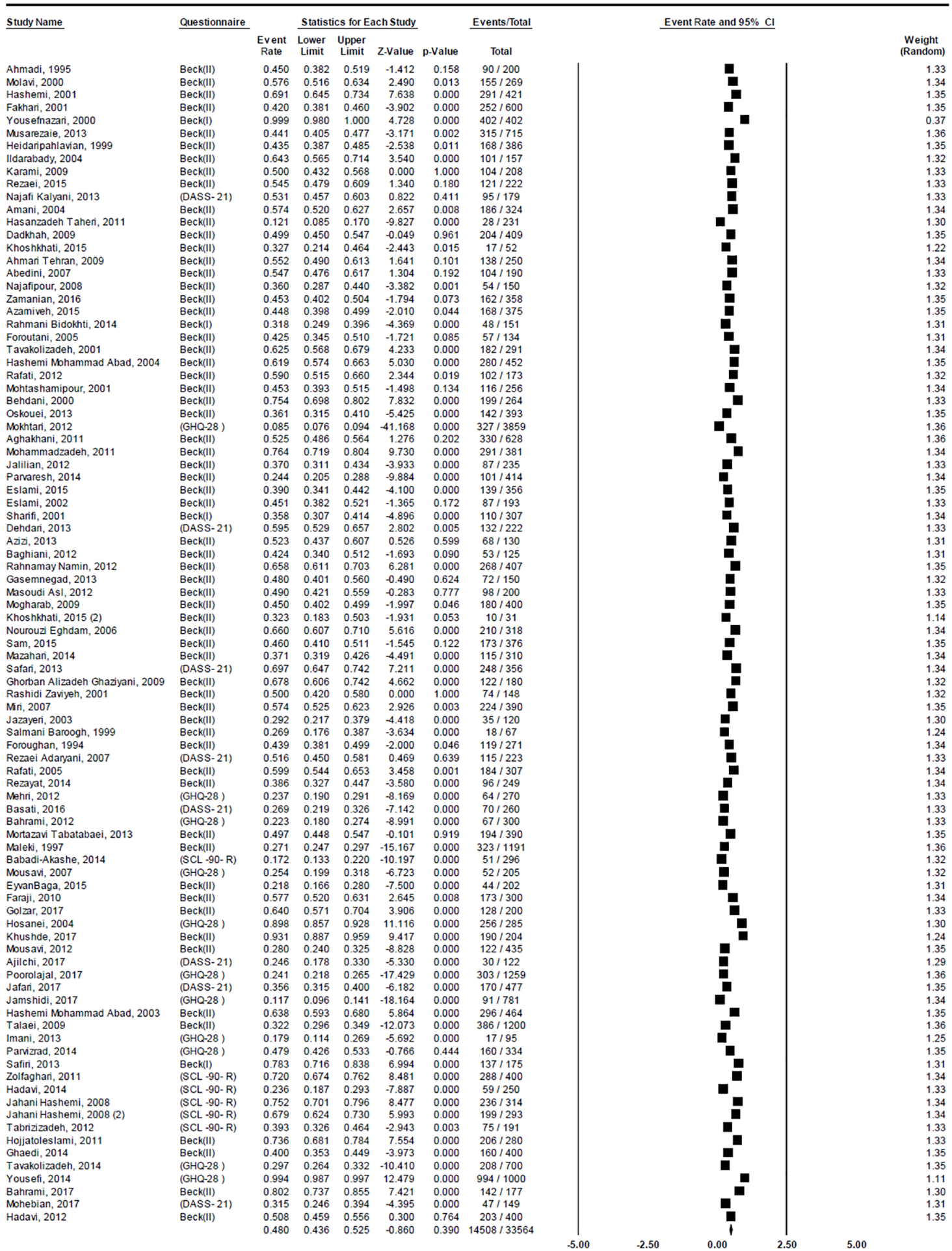

Figure 2. The prevalence of depression in Iranian college students; Random effect model 
Meta-Analysis

\begin{tabular}{|c|c|c|c|}
\hline Study Name & Questionnaire & & Statistics \\
\hline & & Point & $\begin{array}{c}\text { Lower } \\
\text { Limit }\end{array}$ \\
\hline Ahmadi, 1995 & Beck(II) & 0.481 & 0.436 \\
\hline Mblavi, 2000 & Beck(II) & 0.479 & 0.434 \\
\hline Hashemi, 2001 & Beck(II) & 0.478 & 0.433 \\
\hline Falkhan, 2001 & Beck(II) & 0.481 & 0.436 \\
\hline Yousefnazari, 2000 & Beck(l) & 0.475 & 0.431 \\
\hline Musarezaie, 2013 & Beck(II) & 0.481 & 0.436 \\
\hline Heidaripahlavian, 1999 & Beck(II) & 0.481 & 0.436 \\
\hline IIdarabady, 2004 & Beck(II) & 0.479 & 0.434 \\
\hline Karami, 2009 & Beck(II) & 0.480 & 0.435 \\
\hline Rezaei, 2015 & Beck(II) & 0.480 & 0.435 \\
\hline Najafi Kalyani, 2013 & (DASS-21) & 0.480 & 0.435 \\
\hline Amani, 2004 & Beck(II) & 0.479 & 0.434 \\
\hline Hasanzadeh Taheri, 2011 & Beck(II) & 0.485 & 0.441 \\
\hline Dadkhah, 2009 & Beck(II) & 0.480 & 0.435 \\
\hline Khoshkhati, 2015 & Beck(ll) & 0.482 & 0.437 \\
\hline Ahmari Tehran, 2009 & Beck(II) & 0.480 & 0.435 \\
\hline Abedini, 2007 & Beck(II) & 0.480 & 0.435 \\
\hline Najafipour, 2008 & Beck(II) & 0.482 & 0.437 \\
\hline Zamanian, 2016 & Beck(II) & 0.481 & 0.436 \\
\hline Azamiveh, 2015 & Beck(II) & 0.481 & 0.436 \\
\hline Rahmani Bidokhti, 2014 & Beck(l) & 0.482 & 0.437 \\
\hline Foroutani, 2005 & Beck(II) & 0.481 & 0.436 \\
\hline Tavakolizadeh, 2001 & Beck(II) & 0.479 & 0.434 \\
\hline Hashemi Mohammad Abad, 2004 & Beck(II) & 0.479 & 0.434 \\
\hline Rafati, 2012 & Beck(II) & 0.479 & 0.434 \\
\hline Mohtashamipour, 2001 & Beck(II) & 0.481 & 0.436 \\
\hline Behdani, 2000 & Beck(II) & 0.477 & 0.433 \\
\hline Oskouei, 2013 & $\operatorname{Beck}(I I)$ & 0.482 & 0.437 \\
\hline Mbkhtari, 2012 & $(G H Q-28)$ & 0.485 & 0.447 \\
\hline Aghakhani, 2011 & Beck(II) & 0.480 & 0.435 \\
\hline Mbhammadzadeh, 2011 & Beck(II) & 0.477 & 0.433 \\
\hline Jalilian, 2012 & Beck(II) & 0.482 & 0.437 \\
\hline $\begin{array}{l}\text { Parvaresh, } 2014 \\
\text { P. }\end{array}$ & Beck(II) & $\begin{array}{l}0.482 \\
0.483\end{array}$ & 0.439 \\
\hline Eslami, 2015 & Beck(II) & 0.481 & 0.436 \\
\hline Eslami, 2002 & Beck(II) & 0.481 & 0.436 \\
\hline Shanifi, 2001 & Beck(l) & 0.482 & 0.437 \\
\hline Dehdari, 2013 & (DASS-21) & 0.479 & 0.434 \\
\hline$A z j \dot{2}, 2013$ & Beck(II) & 0.480 & 0.435 \\
\hline Baghiani, 2012 & Beck(II) & 0.481 & 0.436 \\
\hline Rahnamay Namin, 2012 & Beck(II) & 0.478 & 0.434 \\
\hline Gasemnegad, 2013 & Beck(II) & 0.480 & 0.436 \\
\hline Masoudi Asl, 2012 & Beck(II) & 0.480 & 0.435 \\
\hline Mbgharab, 2009 & Beck(II) & 0.481 & 0.436 \\
\hline Khoshkhati, 2015 (2) & Beck(II) & 0.482 & 0.437 \\
\hline Nourouzi Eghdam, 2006 & Beck(II) & 0.478 & 0.434 \\
\hline Sam, 2015 & Beck(II) & 0.481 & 0.436 \\
\hline Mazahari, 2014 & Beck(II) & 0.482 & 0.437 \\
\hline Safari, 2013 & (DASS-21) & 0.478 & 0.433 \\
\hline Ghorban Alizadeh Ghaziyani, 2009 & Beck(II) & 0.478 & 0.433 \\
\hline Rashidi Zaviyeh, 2001 & Beck(II) & 0.480 & 0.435 \\
\hline Min, 2007 & Beck(II) & 0.479 & 0.434 \\
\hline Jazayen, 2003 & Beck(II) & 0.483 & 0.438 \\
\hline Salmani Baroogh, 1999 & Beck(II) & 0.483 & 0.438 \\
\hline Foroughan, 1994 & Beck(II) & 0.481 & 0.436 \\
\hline Rezaei Adaryani, 2007 & (DASS-21) & 0.480 & 0.435 \\
\hline Rafati, 2005 & Beck(II) & 0.479 & 0.434 \\
\hline Rezayat, 2014 & Beck(II) & 0.482 & 0.437 \\
\hline Mehri, 2012 & $(\mathrm{GHQ}-28)$ & 0.483 & 0.439 \\
\hline Basati, 2016 & (DASS-21) & 0.483 & 0.438 \\
\hline Bahrami, 2012 & $(G H Q-28)$ & 0.484 & 0.439 \\
\hline Mbrtazavi Tabatabaei, 2013 & Beck(II) & 0.480 & 0.435 \\
\hline Maleki, 1997 & Beck(II) & 0.483 & 0.438 \\
\hline Babadi-Akashe, 2014 & $(\mathrm{SCL}-90-\mathrm{R})$ & 0.484 & 0.440 \\
\hline Mbusavi, 2007 & (GHQ-28) & 0.483 & 0.438 \\
\hline ExvanBaga, 2015 & Beck(II) & 0.484 & 0.439 \\
\hline $\begin{array}{l}\text { Faraji, } 2010 \\
\text { Pa }\end{array}$ & Beck(ll) & 0.479 & 0.434 \\
\hline Golzar, 2017 & Beck(II) & 0.479 & 0.434 \\
\hline Hosanei, 2004 & $(G H Q-28)$ & 0.474 & 0.430 \\
\hline Khushde, 2017 & Beck(II) & 0.473 & 0.429 \\
\hline Mbusavi, 2012 & Beck(II) & 0.483 & 0.438 \\
\hline Ajilchi, 2017 & (DASS-21) & 0.483 & 0.438 \\
\hline Poorolajal, 2017 & (GHQ-28) & 0.483 & 0.439 \\
\hline Jafari, 2017 & (DASS-21) & 0.482 & 0.437 \\
\hline Jamshidi, 2017 & $(G H Q-28)$ & 0.486 & 0.442 \\
\hline Hashemi Mbhammad Abad, 2003 & Beck(II) & 0.479 & 0.434 \\
\hline Talaei, 2009 & Beck(II) & 0.482 & 0.437 \\
\hline Imani, 2013 & $(G H Q 28)$ & 0.484 & 0.439 \\
\hline Parvizad, 2014 & (GHQ-28) & 0.480 & 0.435 \\
\hline Safini, 2013 & $\operatorname{Beck}(l)$ & 0.477 & 0.432 \\
\hline Zolfaghari, 2011 & $(\mathrm{SCL}-90-\mathrm{R})$ & 0.477 & 0.433 \\
\hline Hadavi, 2014 & (SCL -90-R) & 0.483 & 0.439 \\
\hline Jahani Hashemi, 2008 & (SCL -90-R) & 0.477 & 0.433 \\
\hline Jahani Hashemi, 2008 (2) & (SCL -90-R) & 0.478 & 0.433 \\
\hline Tabrizzzadeh, 2012 & (SCL -90-R) & 0.481 & 0.437 \\
\hline Hojjatoleslami, 2011 & Beck(II) & 0.477 & 0.433 \\
\hline Ghaedi, 2014 & Beck(II) & 0.481 & 0.436 \\
\hline Tavakolizadeh, 2014 & (GHQ-28) & 0.483 & 0.438 \\
\hline Yousefi, 2014 & (GHQ-28) & 0.468 & 0.424 \\
\hline Bahrami, 2017 & Beck(II) & 0.476 & 0.432 \\
\hline Mbhebian, 2017 & (DASS-21) & 0.482 & 0.438 \\
\hline Hadavi, 2012 & Beck(ll) & 0.480 & 0.435 \\
\hline & & 0.480 & 0.436 \\
\hline & & & \\
\hline
\end{tabular}




\begin{tabular}{|c|c|c|c|c|c|c|c|}
\hline \multirow{2}{*}{ Variables } & \multirow{2}{*}{ Studies (N) } & \multirow{2}{*}{ Sample (N) } & \multicolumn{3}{|c|}{ Heterogeneity } & \multirow{2}{*}{ 95\% CI } & \multirow{2}{*}{ Prevalence (\%) } \\
\hline & & & $\mathbf{I}^{2}$ & P-Value & $\tau^{2}$ & & \\
\hline \multicolumn{8}{|l|}{ Gender $^{a}$} \\
\hline Male & 33 & 6593 & 97.57 & $<0.001$ & 1.390 & $41.1-61.4$ & 51.3 \\
\hline Female & 41 & 11930 & 97.58 & $<0.001$ & 0.778 & $41.0-54.8$ & 48.9 \\
\hline \multicolumn{8}{|l|}{ Intensity $^{\mathbf{b}}$} \\
\hline Mild & 68 & 20861 & 92.90 & $<0.001$ & 0.232 & $23.8-28.6$ & 26.1 \\
\hline Moderate & 68 & 20861 & 96.17 & $<0.001$ & 0.634 & $13.1-18.3$ & 15.5 \\
\hline Severe & 68 & 20861 & 95.06 & $<0.001$ & 0.938 & $5.1-8.0$ & 6.4 \\
\hline \multicolumn{8}{|l|}{$\begin{array}{l}\text { Questionnaires } \\
\text { c }\end{array}$} \\
\hline Beck(II) & 62 & 19709 & 96.10 & $<0.001$ & 0.344 & $45.7-53.2$ & 49.5 \\
\hline $\operatorname{Beck}(\mathrm{I})$ & 4 & 1035 & 97.26 & $<0.001$ & 1.308 & $38.8-88.1$ & 68.4 \\
\hline GHQ-28 & 11 & 9088 & 99.09 & $<0.001$ & 1.303 & $24.6-56.1$ & 39.2 \\
\hline DASS-21 & 8 & 1988 & 96.22 & $<0.001$ & 0.473 & $32.3-55.8$ & 43.7 \\
\hline SCL-90-R & 6 & 1744 & 98.56 & $<0.001$ & 1.237 & $27.8-69.8$ & 48.5 \\
\hline \multicolumn{8}{|l|}{$\begin{array}{l}\text { Type of } \\
\text { university }\end{array}$} \\
\hline $\begin{array}{l}\text { Univer- } \\
\text { sity of } \\
\text { medical } \\
\text { science }\end{array}$ & 61 & 19819 & 97.14 & $<0.001$ & 0.515 & $41.8-51.0$ & 46.3 \\
\hline $\begin{array}{l}\text { Public } \\
\text { univer- } \\
\text { sity }\end{array}$ & 7 & 3360 & 98.25 & $<0.001$ & 0.597 & $44.1-71.7$ & 58.6 \\
\hline $\begin{array}{l}\text { Islamic } \\
\text { Azad Uni- } \\
\text { versity }\end{array}$ & 8 & 2309 & 95.95 & $<0.001$ & 0.462 & $41.5-66.2$ & 54.1 \\
\hline $\begin{array}{l}\text { Payame } \\
\text { Noor Uni- } \\
\text { versity }\end{array}$ & 2 & 4259 & 99.85 & $<0.001$ & 5.517 & $1.8-92.7$ & 32.8 \\
\hline $\begin{array}{l}\text { Various } \\
\text { univer- } \\
\text { sity }\end{array}$ & 13 & 3817 & 97.54 & $<0.001$ & 0.640 & $37.2-58.9$ & 47.9 \\
\hline
\end{tabular}

Abbreviations: $\mathrm{CI}$, confidence interval; $\mathrm{N}$, number.

${ }^{\mathrm{a}}$ Test for subgroup differences; $\mathrm{Q}=0.292, \mathrm{df}(\mathrm{Q})=1, \mathrm{P}=0.589$.

${ }^{\mathrm{b}}$ Test for subgroup differences; $\mathrm{Q}=148.092, \mathrm{df}(\mathrm{Q})=2, \mathrm{P}<0.001$.

C Test for subgroup differences; $\mathrm{Q}=3.777, \mathrm{df}(\mathrm{Q})=4, \mathrm{P}=0.437$.

${ }^{\mathrm{d}}$ Test for subgroup differences; $\mathrm{Q}=3.593, \mathrm{df}(\mathrm{Q})=4, \mathrm{P}=0.464$.

\subsection{Subgroup Analysis Based on the Intensity}

According to the definitions provided for levels of depression in the literature, the prevalence of mild, moderate, and severe depression among university students was estimated at 26.1\% (95\% CI: 23.8 - 28.6\%), 15.5\% (95\% CI: 13.1 - 18.3\%), and 6.4\% (95\% CI: $5.1-8.0 \%$ ), respectively. We also found a significant difference between males and females $(\mathrm{P}<0.001)$ (Table 2).

\subsection{Subgroup Analysis Based on Questionnaires}

In the present study, the prevalence of depression based on the type of data collection tool (i.e. questionnaire) was also evaluated. According to the findings, the highest and lowest prevalence rates of depression belonged to Beck-I [68.4\% (95\% CI: 38.8 - 88.1\%)] and GHQ-28 [39.2\% (95\% CI: 24.6 - 56.1\%)], respectively. However, there was no significant difference in the subgroup analysis $(\mathrm{P}=$ 0.437) (Table 2). 


\subsection{Subgroup Analysis Based on Type of University}

The highest and lowest prevalence rates of depression were found among students of Public Universities (58.6\%; 95\% CI: 44.1 - 71.7\%) and Payame Noor University (32.8\%; 95\% CI: 1.8 - 92.7\%), respectively. The results revealed no significant difference $(\mathrm{P}=0.464)$ (Table 2$)$.

\subsection{Meta-regression}

According to the results of the meta-regression, the prevalence of depression among Iranian university students has been significantly increased during the study pe$\operatorname{riod}(\mathrm{P}<0.001)$ (Figure 4$)$.

\subsection{Publication Bias}

The P-value for publication bias in Begg's tests was estimated at 0.675 , which was not statistically significant (Figure 5).

\subsection{Factors Related to the Depression}

The meta-analysis results of evaluating factors related to depression are provided in Table 3. According to the findings, students 'interest in the field' had a significant negative correlation with depression $(\mathrm{P}<0.001)$.

\section{Discussion}

According to the findings of the present study, about half of the Iranian university students suffer from depression, as evidenced by presented symptoms. Although the results were somehow heterogeneous, the results of the subgroup analysis showed that depression intensity may lead to high heterogeneity. However, this difference may be due to the characteristics (i.e. size) of study samples. It is also accounted for by different measurement tools and various employed methods.

According to the results of systematic reviews and meta-analyses conducted in other countries, the prevalence of depression among university students ranges from 20 to $31.8 \%$ (108-110), indicating that the prevalence in Iranian college students is higher than that in other countries. Besides, based on previous studies, Asians are less likely to report their depression than people in western countries (111). However, the prevalence of depression among Chinese university students is reported at $23.8 \%$ (95\%; CI: $19.9-28.5 \%$ ), which is lower than that in our study (108). This difference may be due to cultural differences and ethnicity, lack of suitable good jobs and/or lack of social support in achieving them, as well as unfavorable economic conditions. Failure to meet course requirements is another potential cause of depression. Differences in the investigation and follow-up processes of depressed people in Iran, as compared to other countries, and/or in the quality of provided prevention and treatment services probably have contributed to the observed difference.

On the other hand, a systematic review of 35 studies (with a total of 9,743 subjects) in Iran for the period of 1995 to 2012 reported a prevalence of 33\% (95\% CI: 32 - 34\%) for depression among Iranian university students (8). In the present meta-analysis, which combined 89 studies with a sample size of 33,564 Iranian college students, the prevalence of depression was 48.0\% (95\% CI: 43.6 - 52.5\%). According to previous systematic reviews and meta-analyses conducted on university students, it seemed reasonable to perform a new systematic review and meta-analysis after six years. In Sarokhani's study, only 35 studies, with 9,743 participants, are reviewed (8), while at that time more than fifty related articles were published. In another previous study, the prevalence of depression has been estimated at about 33\%, while in our study, the prevalence of depression was estimated at $48.0 \%$, which indicates a significant increase. By comparing our results with previous findings, it seems that the trend of depression disorder has increased among Iranian university students, especially when findings were interpreted separated by gender, which the prevalence of depression amounted to more than 50\% among males. In addition, the strengths of this study, compared to previously published meta-analyses, are benefiting from a relatively larger sample size, investigating more recent studies, and covering studies that have used different data collection tools.

Findings regarding the association between age and the occurrence of depression are inconsistent. Although some studies reported the effect of age on depression, some others mentioned the interactive effect of age with income, childhood abuse index, pain, body mass index, and the number of chronic diseases. That is, the effect of these factors is larger than that of age. In this study, most articles did not mention age, but based on our analysis, we did not find any significant association within age groups. It worth noting that most students cover a limited age range (18 to 30 years old), which may be a reason for not finding any association between age and depression (112).

We found no significant difference between male and female students regarding the prevalence of depression, which is consistent with the results of previous studies (113115). However, contrary to our findings, some studies reported higher rates of depression among female university students (116). On the other hand, a previous systematic review and meta-analysis found a higher prevalence of depression among male university students than in females (8), which is consistent with our findings. Furthermore, previous findings mentioned male gender as an important risk factor of suicidal ideation (117), as well as alcohol and drug abuse (118). 


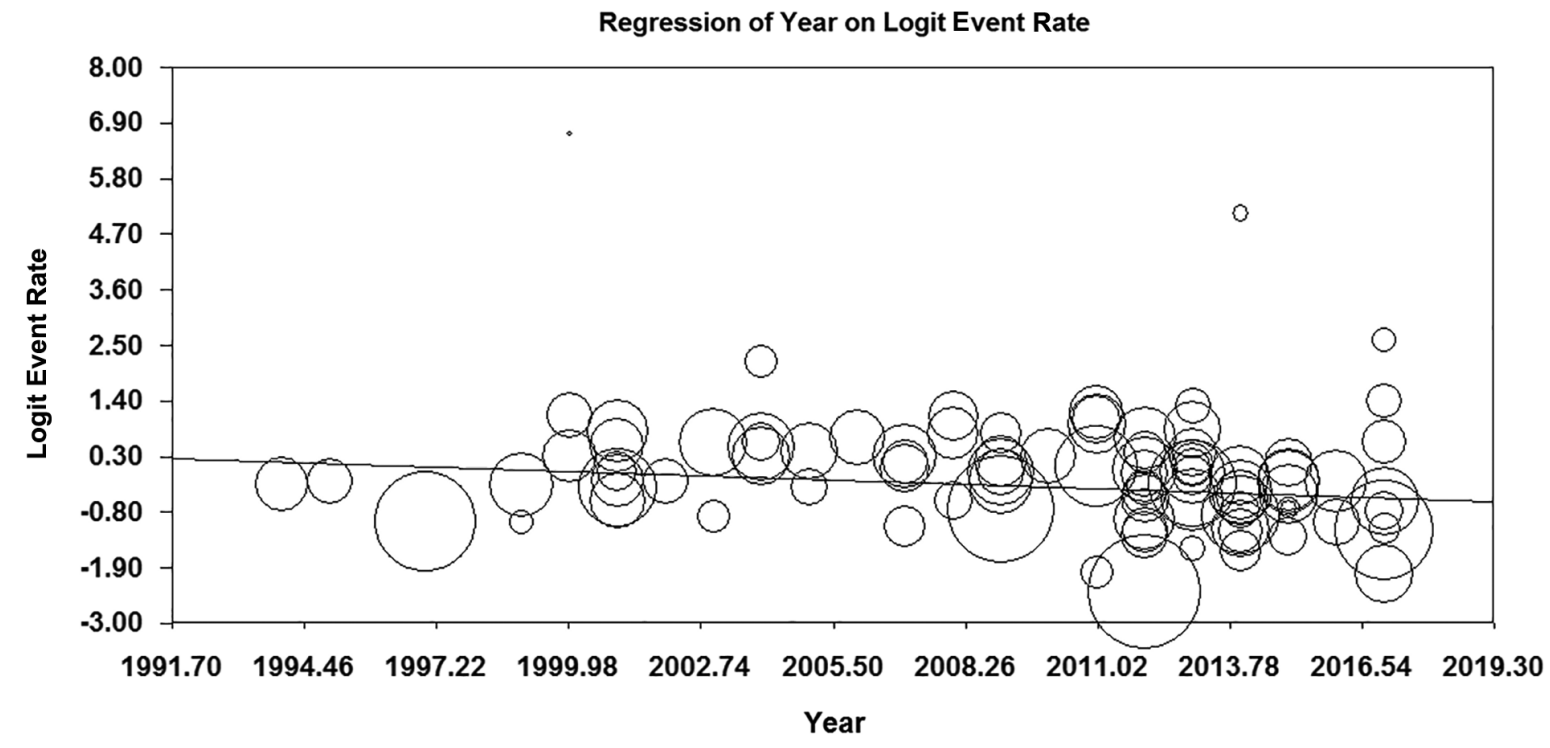

Figure 4. Relationship between depression in Iranian college students and year of study

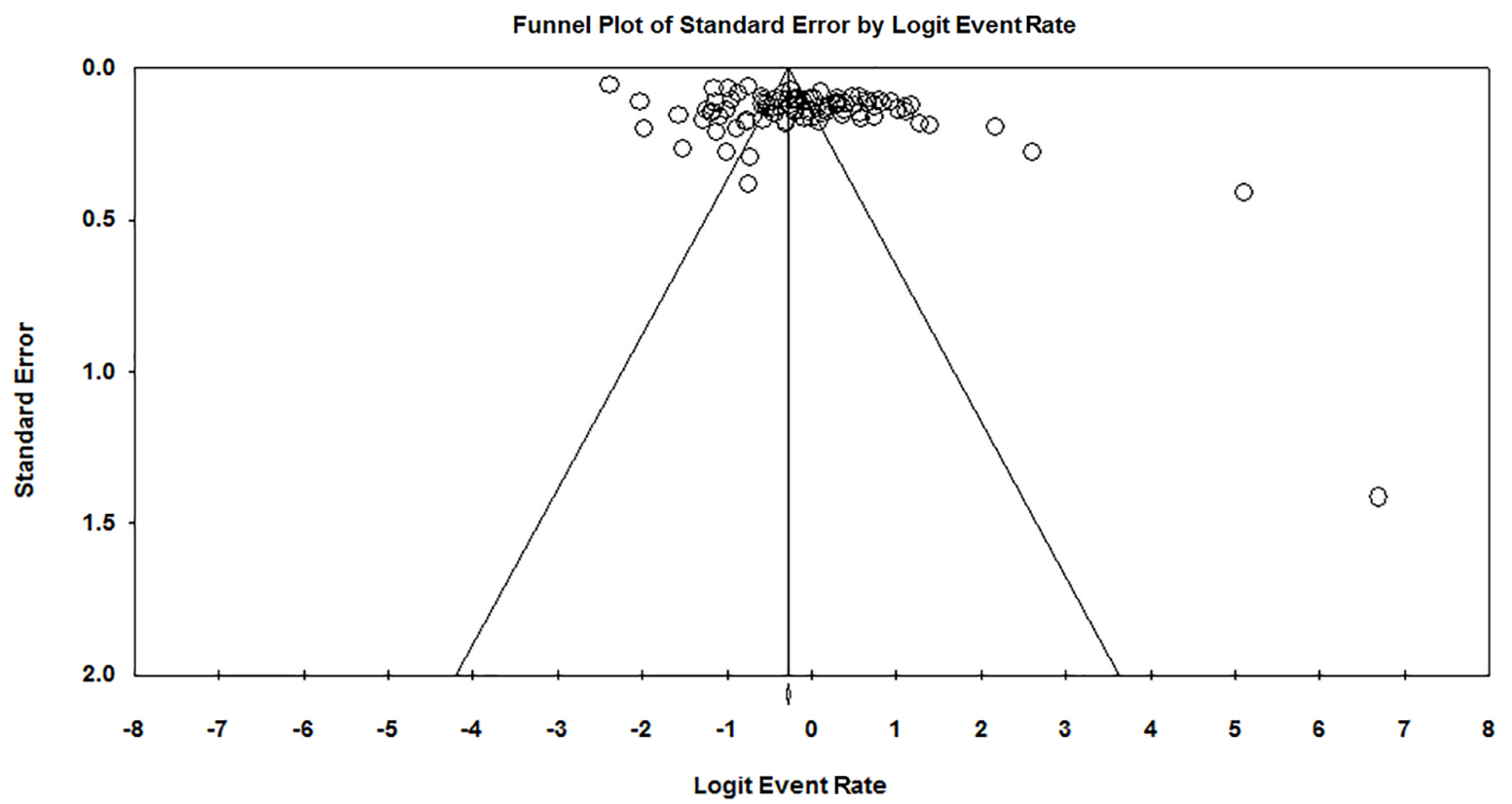

Figure 5. Publication bias of depression in Iranian college students

The association between marital status and depression symptoms is well documented (119). However, the clinical findings mentioned the contribution of other factors. For instance, this association is modified by age and gen- der (120). Although in the present study little information were available about marital status and most studies did not address the marital status of their participants, we did not find any significant association between mari- 


\begin{tabular}{|c|c|c|c|c|c|c|c|c|}
\hline \multirow{2}{*}{ Variables } & \multirow{2}{*}{ Studies (N) } & \multicolumn{2}{|c|}{ Sample (N) } & \multicolumn{3}{|c|}{ Heterogeneity } & \multirow{2}{*}{ OR $(95 \% \mathrm{CI})$} & \multirow{2}{*}{ P-Value } \\
\hline & & Case & Control & $\mathbf{I}^{2}$ & P-Value & $\tau^{2}$ & & \\
\hline Marital status & 11 & 1894 & 1485 & 91.04 & $<0.001$ & 1.363 & $1.25(0.59-2.62)$ & 0.54 \\
\hline Native status & 10 & 1312 & 1074 & 61.82 & 0.005 & 0.188 & $0.70(0.49-1.01)$ & 0.059 \\
\hline Interest in the field & 7 & 683 & 695 & 55.52 & 0.03 & 0.214 & $0.32(0.20-0.52)$ & $<0.001$ \\
\hline \multicolumn{9}{|l|}{ Age group (y) } \\
\hline$<$ Or $>20$ & 6 & 1394 & 1175 & 66.41 & 0.01 & 0.121 & $0.83(0.58-1.18)$ & 0.31 \\
\hline$<$ Or $>25$ & 6 & 1279 & 1228 & 61.10 & 0.02 & 0.208 & $1.03(0.62-1.70)$ & 0.90 \\
\hline
\end{tabular}

Abbreviations: $\mathrm{CI}$, confidence interval; $\mathrm{N}$, number.

tal status and depression. The prevalence rates of depression among Iranian university students at different levels of intensity were estimated at 26.1, 15.5, and 6.4\% for mild, moderate, and severe depression, respectively. The fact that most of the depressed people have mild symptoms suggests that clinical and psychological programs and treatments could prevent the development of depression among Iranian university students, which in turn prevented the further consequences of the disease.

In the present study, the reported rates of depression prevalence among Iranian university students ranged from 39.2 to $68.4 \%$. The most probable cause of such a wide range of prevalence is the diversity of applied diagnostic tools, including Beck-II, Beck-I, GHQ-28, SCL-90- R, and DASS-21. For instance, in the study by Ghaedi et al. (103), who used the Beck-II questionnaire to assess depression, a prevalence of $40 \%$ is reported, while in studies that had used the GHQ-28 questionnaire, a prevalence of 29.7 is reported (104). In our study, the subgroup analysis, according to the applied questionnaires, did not provide significant results.

The highest and lowest prevalence rates of depression were in students of public universities [58.6\% (95\% CI: 44.1 - 71.7\%)] and Payame Noor University [32.8\% (95\% CI: 1.8 - 92.7\%)], respectively. This difference can be attributed to the higher academic pressure in public universities as compared to Payame Noor University. In fact, studying at public universities is much more competitive and highly more demanding than at other universities, including Payame Noor University. In addition, graduates of public universities are expected to find better jobs.

In this study, a meta-regression model was used to find the prevalence of depression among university students vis-a-vis the year of study. There was a significant association between the prevalence of depression among university students and the year of study. This may be due to increased economic pressures and inadequate economic conditions of families, reduced physical activity, as well as nutritional factors like consumption of more fast food during college education. Findings also suggested that negative life events, such as failure in love, separation of parents, and financial problems, are direct sources of depression. University students with more negative life experiences are at an increased risk of developing depression (121). In addition, the study by Lipson et al. (2018), which examined the healthy minds study(HMS) of US students over a ten-year period (2007 - 2017), indicated an increase in depression among college students, which is in line with the results of the present study (122).

Various factors contribute to the development of depression. In the present study, interest in the field of study had a significantly reverse association with depression among Iranian university students, which is similar to the results of other studies $(27,43,58,60,72,97,106)$, which in turn indicates that educating the students on how to select a field of study before entering the university can reduce depression prevalence among university students. The results of these studies also show that families should not force their children to study in a field that they are not interested in. Because studying a field that is not interested, not only prevents them from success, but also may cause health problems (58). Starting university education requires several changes and adjustments in such a way that students can enter their favorite fields of study without too much difficulty. Families, and society at a wider spectrum, should also respect students' preferences more and simultaneously avoid putting pressure on them in making their academic choices.

\subsection{Strengths and Limitations}

It is necessary to mention some strengths and limitations of our study. One of the most important strengths is performing a more comprehensive literature review. Besides, a more systematic methodology has been employed 
in treating the collected data, one that includes a range of meta-analyses. The present study entails, however, a number of inevitable limitations. Firstly, the national databases did not provide the possibility of doing a combined search. Secondly, some risk factors (e.g. the history of depression, religious orientations, and familial economic conditions) could not be included in the analyses as few studies have addressed such issues. This points to the need for more qualitative studies to explore other factors associated with the prevalence of depression among Iranian university students to provide a more comprehensive understanding of the problem.

In Conclusion, the findings of this review point to the fact that the prevalence of depression among Iranian college students is high. The review not only highlights the existing gaps in the literature on depression among Iranian college students, but also the need for interventions to reduce the prevalence rate of depression in universities. Future studies in this field should more focus on the characteristics of the participants to find key factors that contribute to the prevalence of depression. We hope this metaanalysis, which summarized research findings published over the past 25 years, can serve as a warning to university administrations. The results of our study should stimulate not only more research on university students, as a distinct group, but also encourage families, universities, and society, as a whole, to develop and implement strategies to help the young to overcome their difficulties, which in turn leads to a healthier life.

\section{Acknowledgments}

We are thankful to the Bushehr University of Medical Sciences, Bushehr, Iran for financial support. Also, we acknowledged the Clinical Research Development Center, The Persian Gulf Martyrs Hospital, Bushehr University of Medical Science.

\section{Footnotes}

Authors' Contribution: Performed the literature search, Z.J., M.M, and F S.M; Performed quality evaluation, H.M, and E.D; Performed data extraction and statistical analysis, Z.J, and M.M; Wrote the manuscript, Z.J, and M.M; Revised the manuscript, A.F, and F.A L. All authors read and approved the final manuscript.

Conflict of Interests: The authors declare no conflict of interests.

Ethical Approval: This study was not performed on human specimens.

Funding/Support: Bushehr University of Medical Sciences, Bushehr, Iran financially supported the study.

\section{References}

1. Sadock BJ, Sadock VA, Ruiz P. Mood disorder. Kaplan and Sadock's comprehensive textbook of psychiatry. Philadelphia, Pennsylvania, United States: Lippincott Williams \& Wilkins; 2009.

2. GBD 2017 Disease and Injury Incidence and Prevalence Collaborators. Global, regional, and national incidence, prevalence, and years lived with disability for 354 diseases and injuries for 195 countries and territories, 1990-2017: A systematic analysis for the global burden of disease study 2017. Lancet. 2018;392(10159):1789-858. doi: 10.1016/S0140-6736(18)32279-7. [PubMed:30496104]. [PubMed Central: PMC6227754]

3. Hadavi M, Rostami N. [Depression and its effective factors among the students of Rafsanjan nursing, midwifery and paramedical faculty2012]. J Community Health. 2017;6(3):58-65. Persian.

4. Nan H, Lee PH, McDowell I, Ni MY, Stewart SM, Lam TH. Depressive symptoms in people with chronic physical conditions: prevalence and risk factors in a Hong Kong community sample. BMC Psychiatry. 2012;12:198. doi: 10.1186/1471-244X-12-198. [PubMed: 23151217]. [PubMed Central: PMC3534521].

5. Sullivan PF, Neale MC, Kendler KS. Genetic epidemiology of major depression: review and meta-analysis. Am JPsychiatry.2000;157(10):155262. doi: 10.1176/appi.ajp.157.10.1552. [PubMed: 11007705].

6. Cassano P, Fava M. Depression and public health: An overview. J Psychosom Res. 2002;53(4):849-57. doi: 10.1016/s0022-3999(02)00304-5. [PubMed: 12377293].

7. Cole MG, Dendukuri N. Risk factors for depression among elderly community subjects: A systematic review and meta-analysis. Am JPsychiatry. 2003;160(6):1147-56. doi: 10.1176/appi.ajp.160.6.1147. [PubMed: 12777274].

8. Sarokhani D, Delpisheh A, Veisani Y, Sarokhani MT, Manesh RE, Sayehmiri K. Prevalence of depression among university students: A systematic review and meta-analysis study. Depress Res Treat. 2013;2013:373857. doi: 10.1155/2013/373857. [PubMed: 24187615]. [PubMed Central: PMC3800630].

9. Kessler RC, Berglund P, Demler O, Jin R, Koretz D, Merikangas KR, et al. The epidemiology of major depressive disorder: Results from the national comorbidity survey replication (NCS-R). JAMA. 2003;289(23):3095-105. doi: 10.1001/jama.289.23.3095. [PubMed: 12813115].

10. Buchanan JL. Prevention of depression in the college student population: A review of the literature. Arch Psychiatr Nurs. 2012;26(1):21-42. doi: 10.1016/j.apnu.2011.03.003. [PubMed: 22284078].

11. Cuellar I, Roberts RE. Relations of depression, acculturation, and socioeconomic status in a Latino sample. Hisp J Behav Sci.2016;19(2):2308. doi: 10.1177/07399863970192009.

12. Eller T, Aluoja A, Vasar V, Veldi M. Symptoms of anxiety and depression in Estonian medical students with sleep problems. Depress Anxiety. 2006;23(4):250-6. doi:10.1002/da.20166. [PubMed:16555263].

13. Reavley N, Jorm AF. Prevention and early intervention to improve mental health in higher education students: A review. Early Interv Psychiatry. 2010;4(2):132-42. doi:10.1111/j.1751-7893.2010.00167.x. [PubMed: 20536969].

14. Moher D, Liberati A, Tetzlaff J, Altman DG; Prisma Group. Preferred reporting items for systematic reviews and meta-analyses: The PRISMA statement. Ann Intern Med. 2009;151(4):264-9. W64. doi:10.7326/00034819-151-4-200908180-00135. [PubMed: 19622511].

15. Richardson WS, Wilson MC, Nishikawa J, Hayward RS. The well-built clinical question: A key to evidence-based decisions. ACP J Club. 1995;123(3):A12-3. [PubMed: 7582737].

16. Poorolajal J, Cheraghi Z, Irani AD, Rezaeian S. Quality of cohort studies reporting post the strengthening the reporting of observational studies in epidemiology (STROBE) statement. Epidemiol Health. 2011;33. e2011005. doi: 10.4178/epih/e2011005. [PubMed: 21716598]. [PubMed Central: PMC3110877]. 
17. Ades AE, Lu G, Higgins JP. The interpretation of random-effects metaanalysis in decision models. Med Decis Making. 2005;25(6):646-54 doi: 10.1177/0272989X05282643. [PubMed:16282215].

18. Higgins JP, Thompson SG, Deeks JJ, Altman DG. Measuring in consistency in meta-analyses. BMJ. 2003;327(7414):557-60. doi: 10.1136/bmj.327.7414.557. [PubMed: 12958120]. [PubMed Central: PMC192859].

19. Borenstein M, Hedges LV, Higgins JP, Rothstein HR. A basic introduction to fixed-effect and random-effects models for meta-analysis. Res Synth Methods. 2010;1(2):97-111. doi: 10.1002/jrsm.12. [PubMed: 26061376].

20. Ahmadi J. The prevalence of depression in medical students. Journal of Thought \& Behavior in Clinical Psychology.1995;1(6).

21. Molavi P, Karimollahi M. Prevalence of depression in Ardabil medical students. Annals of General Psychiatry. 2006;5(S1). doi: 10.1186/1744859x-5-s1-s149.

22. Hashemi N, Kamkar A. [A study on the prevalence of depression in students of Yasuj University of Medical Sciences]. Armaghan Danesh. 2001;6(21-22):14-21. Persian.

23. Fakhari ]. [Prevalence of depression among athletic and non athlete students of Tabriz University in 2000-2001]. Faculty of Literature and Human Sciences of Tabriz University. 2001;(180-181):179-86. Persian.

24. Yousefnazari F. [Prevalence of depression and its relationship with students' tendency and academic satisfaction in Islamic Azad University]. Proceedings of the Humanities. 2000;2:215-34. Persian.

25. MousaRezaie A, NajiEsfehani H, Khosravi N, Momeni-Ghaleghasemi T, Masaeli N. [Relationship between commitment and priority to prayer with depression and some demographic parameter]. Journal of Research in Behavioural Sciences. 2013;10(6):441-52. Persian.

26. Heidari Pahlavian A, Mahjob H, Zarrabian M. [The relationship between intenud and external locus of control, depression and educational performance among Hamedan medical school students]. Iran J Psychiatry Clin Psychol.1999;4(4):23-32. Persian.

27. Ildarabady E, Firouzkouhi MR, Navidian A. [Prevalence of depression among students of Zabol Medical School, 2002].J Shahrekord Univ Med Sci. 2004;6(2):15-21. Persian.

28. Karami M. [The study of the rate of depression in allied health faculty students of Kashan University Of Medical Sciences in 2008]. Nurs Midwifery J. 2009;7(3):166-72. Persian.

29. Rezaei T, Yazdi-Ravandi S, Ghaleiha A, Seif Rabiei MA. [Depression among medical students of Hamadan University of Medical Sciences in 2014: The role of demographic variables]. Pajouhan Scientific Journal. 2015;13(4):1-8. Persian.

30. Najafi Kalyani M, Pourjam E, Jamshidi N, Karimi S, Najafi Kalyani V. [Survey of stress, anxiety, depression and self-concept of students of Fasa University of Medical Sciences, 2010]. J Fasa Univ Med Sci. 2013;3(3):235-40. Persian.

31. Amani F, Sadeghieh S, Azami A, Ojaghi H. [Comparative survey on mistake rate between educators with optometrists examinations in performance amblyopia research in Ardabil province, 2002].JArdabil Univ Med Sci. 2002;2(4):7-11. Persian.

32. Hasanzadeh Taheri MM, Mogharab M, Akhbari SH, Raeisoon MR, Hasanzadeh Taheri E. [Prevalence of depression among new registered students in Birjand University of Medical Sciences in the academic year 2009-2010]. J Birjand Univ Med Sci. 2011;18(2):109-16. Persian.

33. Dadkhah B, Mohammadi M, Mozafari N, Mohammadnejad S, Dadkhah D. [Prevalence of depression in students of Ardabil University of Medical Sciences]. Nurs Midwifery J. 2009;11(1):28-32. Persian.

34. Khoshkhati N, Jafari A, Yazdinezhad A. [Prevalence of depression among freshmen of pharmacy at Zanjan University Of Medical Sciences according demographic parameters]. J Med Educ Dev. 2015;8(17):21-8. Persian.

35. Ahmari Tehran $\mathrm{H}$, Heydari A, Kachouei A, Moghiseh M, Irani A [The relationship between depression and religious attitudes in students of Qom University of Medical Sciences, Qom, Iran]. Qom UMSJ. 2009;3(3):51-6. Persian.
36. Abedini S, Davachi A, Sahbaei F, Mahmoudi M, Safa O. [Depression in medical and nursing students, Bandar Abbas]. HMJ. 2007;11(2):139-45 Persian.

37. Najafipour S, Yektatalab SH. The prevalence of depression among the students of Jahrom University of medical sciences and its relationship with academic failure. J Jahrom Univ Med Sci. 2008;6(2):27-37.

38. Zamanian Z, Riaei S, Kaveh N, Khosravani A, Daneshmandi H, Sayadi M. [Determining the prevalence of depression and its associated factors in students of Shiraz University of Medical Sciences, Iran]. Health Sys Res. 2016;12(1):38-43. Persian.

39. Azarniveh MS, Tavakoli Khormizi SA. [Depression and academic achievements in athletes and non-athletes university students: A comparative study]. IJN. 2015;28(96):1-10. Persian. doi: 10.29252/ijn.28.96.1.

40. Rahmani Bidokhti N, Sadeghi Khorashad M, Bijari B. [Comparisonof depression prevalence in medical students between the first and last years of Birjand University of Medical Sciences: Brief article].J Birjand Univ Med Sci. 2014;21(2):246-52. Persian.

41. Foroutani M. [Depression in some college students]. IJN 2005;18(41):123-30. Persian.

42. Tavakoli J, Mohammad Pour A. [The survey of student depression in Gonabad College of Medical Sciences]. Ofogh-e-Danesh. 2001;7(1). Persian.

43. Hashemi Mohammadabad S, Hosseini Z, Shahami M. [Epidemiological study of depression in students of Islamic Azad University, Yasuj 2001]. Teb va Tazkiye. 2004;(53):99-102. Persian.

44. Rafati F, Pilevarzade M, Mohammadi Solimani M, Salari S, Pormehr A. [Relationship between BMI and mental health in nursing students of Jiroft]. Iran J Endocrinol Metab. 2012;14(2):5. Persian.

45. Mohtashamipour E, Mohtashamipour M, Shadlomashhadi F, Emadzadeh A, Hasanabadi $\mathrm{H}$. [The survey of pray and depression rate relationship in paramedical and health students of Mashhad University]. Ofogh-e-Danesh. 2003;9(1):76-81. Persian.

46. Behdani F, Sargolzaei MR, Ghorbani E. [Study of the relationship between lifestyle and prevalence of depression and anxiety in the students of Sabzevar universities]. J Sabzevar Univ Med Sci. 2000;7(2 (16)):27-37. Persian.

47. Nasiri Oskouei N, Kahkeshan P. A study on depression among paramedical students and the contributing factors in 2010-2011. Arch Adv Biosci. 2013;4:99-105.

48. Mokhtari M, Ghasembaklo U, Mohammadyari G, Mohammadzadeh M, Behestani M. A study of mental health of university students in West Azerbaijan in Iran. J Basic Appl Sci Res. 2012;2(12):13188-94.

49. Aghakhani N, Nia HS, Eghtedar S, Rahbar N, Jasemi M, Zadeh MM Prevalence of depression among students of Urmia University of Medical Sciences (Iran). Iran J Psychiatry Behav Sci. 2011;5(2):131-5. doi 10.1016/S0924-9338(11)72303-3. [PubMed: 24644458]. [PubMed Central: PMC3939964].

50. Mohammadzadeh J. [Investigation of prevalence rate of depression symptoms among Ilam University students]. J Ilam Uni Med Sci. 2011;19(2):71-6. Persian

51. Jalilian F, Emdadi S, Karimi M, Barati M, Gharibnavaz H. [Depression among collage students the role of general self-efficacy and perceived social support]. Avicenna J Clin Med. 2012;18(4):60-6. Persian.

52. Parvaresh N, Ziaadini H, Erfani R, Shokoohi M. [Prevalence of attention deficit hyperactivity disorder and its relation with depression].J Gorgan Univ Med Sci. 2014;16(1):94-8. Persian.

53. Eslami Akbar R, Kooti W, Noori Ahmad Abadi M, Zare Marzoni H Kalani N. [The study of depression prevalence among the students of Jahrom University of Medical Sciences in 2013]. Zanco J Med Sci. 2015;15(47):58-66. Persian.

54. Eslamei AA, Vakili MA, Faraji J. [The study of the rate of depression and its relation to kind of free time acitvity among the medical students] J Gorgan Univ Med Sci. 2002;4(9):52-9. Persian.

55. Sharifi K, Souki Z, Khademi Z, Hosseinian M, Tagharobi Z. [Prevalence of depression and its contributing factors among Kashan Mecial Uni- 
versity students]. Feyz. 2001;16(4):54-8. Persian.

56. Dehdari T, Yarahmadi R, Taghdisi MH, Daneshvar R, Ahmadpoor J. The relationship between meaning in life and depression, anxiety and stress status among college students of Iran university of medical sciences in 2013. Iran J Health Educ Health Promot. 2013;1(3):83-92.

57. Azizi M, Khamseh F, Rahimi A, Barati M. [The relationship between self-esteem and depression in nursing students of a selected medical university in Tehran]. Iran J Psychiatry Nurs. 2013;1(1):28-34. Persian.

58. Baghiani Moghaddam MH, Ehrampoush MH, Rahimi B, Aminian AH, Aram M. [Prevalence of depression among successful and unsuccessful students of Public Health and Nursing-Midwifery schools of Shahid Sadoughi University of Medical Sciences in 2008]. J Med Educ Dev. 2012;6(1):17-24. Persian.

59. Rahnamay Namin M. [Comparison of depression in students of Islamic Azad University living in Takestan, Abhar, and Bouin-Zahra dormitories (2009)].JQUMS. 2012;16(2):83-6. Persian.

60. Ghasemnegad SM, Barchordary M. [Frequency of anxiety and its relation with depression and other individualcharacteristics in nursing students]. J Holist Nurs Midwifery. 2012;22(2):40-7. Persian.

61. Masoudi Asl I. [Evaluation of depression in Nursing Students of Azad University]. Middle Eastern J Disabil Stud. 2012;1(1):42-6. Persian.

62. Mogharab M, Ghanad-e-Kafee M, Rezaee N. [Relationship of depression and praying in Birjand University of Medical Sciences]. Mod Care J. 2009;6(1-4):54-9. Persian.

63. Nourouzi Eghdamm M. [The study of the rate and causes of depression among students of Islamic Azad University of Miyaneh branch and providing solutions for reducing and eliminating it]. Sci J Educ Res. 2006;5(5). Persian.

64. Sam S, Rafie F, Nazeri M, Sam A, Shahravan A. [Assessment and comparison of stress, depression and emotional intelligence among medical sciences and engineering students]. Educ Dev Judishapur. 2015;6(3):220-8. Persian.

65. Mazhari F, Ravari A, Ansari A, Heidari S, Shahabi M. Investigating the relationship between the early rising and depression studied on the students in Rafsanjan University of Medical Sciences. Quran Med. 2014;3(1). e8848. doi: 10.5812/quranmed.8848.

66. Safari Y, Yarmohhamadi H, Sharafi K, Naseraldinpoor Goya A, Falahi B. Assessing of student's cognitive emotional self-regulation and relationship with cognitive emotional self-regulation in Kermanshah University of Medical Sciences. J of Clin Res Paramed Sci. 2013;2(1).

67. Ghorban Alizadeh Ghaziyani F, Tayebi S, Ramezaninejad R. [Comparison of depression of active and inactive students based on demographic characteristics]. J Sport Man Mot Behav. Persian.

68. Rashidi Zaviyeh F. [Depression rate of students at Faculty of Nursing and Midwifery, Zanjan University of Medical Sciences, 2000].JAdv Med Biomed Res. 2001;9(36):44-54. Persian.

69. Miri MR, HajiAbadi MR, Soorgi Z, Qasemi K. [Relationship between depression and level of reliance on God in Birjand university students]. J Birjand Univ Med Sci. 2007;14(4):52-8. Persian.

70. Jazayeri AR, Ghahari S. [Basic approach in assessment of mental health in university students]. J Res Plan High Educ. 2003;9(1-2 (2728)):127-56. Persian.

71. Salmani Barough N, Sharifi Nistanak N, Yousefi F, Mehran A. [Comparative study of depression among internship nursing students in Faculty of Nursing and Midwifery, Tehran University of Medical Sciences and Health Services in 1996-1999]. Hayat. 1999;5(1):18-22. Persian.

72. Foroughan M, Emami H, A'bdi-Farkoush B, Partow-Azar B. [The epidemiologic study of depression in medical students of Bandar Abbas University (1994-1995)]. Arch Rehabil J. 2000;1(1):19-29. Persian.

73. Rezaei Adaryani M, Azadi A, Ahmadi F, Vahedian AA. [Comparison of depression, anxiety, stress and quality of life in dormitories students of Tarbiat Modares University]. Iran J Nurs Res. 2007;2(4-5):31-8. Persian.

74. Rafati F, Sharif F, Ahmadi J, Zeighami B. [Study of the relationship between general health, depression and personality traits of students with their success]. Teb va Tazkiye. 2005;14(3 (58)):25-31. Persian.

75. Rezayat F, Dehgannayeri N. [Relationship between depression and self-efficacy in nursing students]. Iran J Nurs. 2013;26(81):54-63. Persian.

76. Mehri A, Sedighy Some-Koochak Z. [Assessment of mental health status andsome related factorsamong students of Sabzevar Universities in 2010]. Med Sci J Islamic Azad Univ. 2012;21(4):293-304. Persian.

77. Basati M, Rajabi Maram A, Basati M. Study of the relationship between the use of web-based environments with students' depression, anxiety and stress. 2nd Jnternational Conference on Web Research 2016. Tehran, Iran. 2nd Jnternational Conference on Web Research 2016; 2016.

78. Bahrami S, Molakhili H, Baghbani F, AshrafiRizi H, Mojiri S. [Relationship between non-school study and mental health of students of Isfahan University of Medical Sciences]. Iran J Med Edu. 2012;11(9):1241-7. Persian.

79. Mortazavi Tabatabaee A, Ramazan Khani A, Gharli Pour Z, Babaee Haidar Abadi A, Tavasoli E, Matlabi Ghaen M, et al. [Study of effective factors on depression, perceived stress and perceived social support and their relationship among students living in dormitories of Shahid Beheshti University of Medical Sciences]. J Ilam Uni Med Sci. 2013;21(4):99-106. Persian.

80. Maleki H, Mottaghipoor Y, Sadeghifar M. [A study on depression and anxiety related factors in Hamedan Medical Sciences University students]. Tehran Univ Med J.1997;55(6):79-85. Persian.

81. Babadi-Akashe Z, Zamani BE, Abedini Y, Akbari H, Hedayati N. The relationship between mental health and addiction to mobile phones among university students of Shahrekord, Iran. Addict Health . 2014;6(3-4):93. [PubMed: 25984275]. [PubMed Central: PMC4354213].

82. Mousavi SS, Haj Fathali AR, Taghavi A, Bakhshi M. [Evaluation of mental health of nonmilitary medical students at clinical training grade]. Ann Mil Health Sci Res. 2007;5(1 (17)):1127-32. Persian.

83. EyvanBaga R, Nasiri K, Kamran A, Shamkhali R. [The relationship between depression, anxiety and spiritual health among students of Khalkhal Faculty of Medicine Sciences]. J Community Health. 2017;3(3):47-55. Persian.

84. Faraji P, Faraji R, Dideh Roushani S, Nasrolah K. [Prevalence of depression, anxiety and obsessive-compulsive disorder among students]. The 1st Student National Congress on Social Determinants of Health. Tehran, Iran. Civilika; 2011. Persian.

85. Golzar HR, Aflakseir A, Molazadeh J. [Structural equation modeling of dysfunctional attitudes and depression symptoms: Investigation of the mediation role of ruminative response style]. Iran J Psychiatry Clin Psychol. 2017;22(4):318-29. Persian. doi:10.18869/nirp.ijpcp.22.4.318.

86. Hosanei SH, Mosavy MH. [The comparative study of health status of medical students and para-medical students trainee]. J Gorgan Univ Med Sci. 2004;6(13):101-7. Persian.

87. Kouteh B, Khushde S, Farhangi M, Kahrazei F, Ziapour A. A comparative study of homesickness, depression, and internet addiction between native and nonnative students at University of Sistan and Baluchestan, Iran. Ann Trop Med Public Health. 2017;10(6):1537-46. doi: 10.4103/atmph.atmph_498_17.

88. Mousavi SG, Keramatian K, Maracy MR, Fouladi M. Suicidal ideation, depression, and aggression among students of three universities of Isfahan, Iran in 2008. Iran J Psychiatry Behav Sci. 2012;6(1):47-53. [PubMed: 24644469]. [PubMed Central: PMC3939947].

89. Ajilchi B, Nejati V. Executive functions in students with depression, anxiety, and stress symptoms. Basic Clin Neurosci. 2017;8(3):223-32. doi: 10.18869/nirp.bcn.8.3.223. [PubMed: 28781730]. [PubMed Central: PMC5535328].

90. Poorolajal J, Ghaleiha A, Darvishi N, Daryaei S, Panahi S. The prevalence of psychiatric distress and associated risk factors among college students using GHQ-28 Questionnaire. Iran J Public Health. 2017;46(7):957-63. [PubMed: 28845407]. [PubMed Central: PMC5563878].

91. Jafari P, Nozari F, Ahrari F, Bagheri Z. Measurement invariance of the depression anxiety stress scales-21 across medical student genders. Int J Med Educ. 2017;8:116-22. doi: 10.5116/ijme.58ba.7d8b. [PubMed: 
28362630]. [PubMed Central: PMC5376494].

92. Jamshidi F, Mogehi S, Cheraghi M, Jafari SF, Kabi I, Rashidi L. A CrossSectional study of Psychiatric disorders in Medical Sciences Students. Mater Sociomed. 2017;29(3):188-91. doi: 10.5455/msm.2017.29.188-191. [PubMed: 29109664]. [PubMed Central: PMC5644188].

93. Hashemi Mohammadabad N, Zadehbagheri G, Ghafarian Shirazi HR. [A survey on some etiologic factors related to depression among university students in Yasuj]. Journal of Medical Research. 2003;2(1):19-26. Persian.

94. Talaei A, Fayyazi MR, Ardani AR. Depression and its correlation with self-esteem and social support among Iranian university students. Iran J Psychiatry. 2009;4:17-22.

95. Imani E, Khademi Z, Soudagar S, Naghizadeh F. [Health status of nursing students of Hormozgan University of medical sciences by Goldberg's general health questionnaire]. Hormozgan Med J.2013;17(4):35764. Persian.

96. Parvizrad P, Yazdani Charati J, Sadeghi MR, Mohammadi A, Hosseini $\mathrm{H}$. [Relationship between mental health, demographic variables and academic achievement of medical sciences students]. J Mazandaran Univ Med Sci. 2014;23(109):241-6. Persian.

97. Safiri S, Khanjani N, Kusha A, Narimani MR, Karamzad N. Prevalence of depression and its associated factors using beck depression inventory among students of school of health and nutrition, Tabriz, Iran in 2009. J Anal Res Clin Med. 2013;1(2):83-9. doi:10.5681/jarcm.2013.012.

98. Zolfaghari AR, Fathi D, Hashemi M. The study of mental health status of payame-noor university students in Toyserkan, Iran. Procedia Soc Behav Sci. 2011;30:1795-7. doi:10.1016/j.sbspro.2011.10.345.

99. Hadavi M, Yazdani M, Khodadadi A, Hashemi Z, Aminzadeh F. Comparison of the mental health status of First- and last-year students of Nursing, Midwifery and Paramedical Faculty of Rafsanjan based on SCL90 in 2012.J Rafsanjan Univ Med Sci. 2014;13(6):549-60.

100. Jahani Hashemi H, Rahimzadeh Mirmahalleh S, Ghafelehbashy $\mathrm{H}$, Sarichloo ME. [Investigating the mental health of the first- and lastyear students of QUMS (2005)].JInflamm Dis. 2008;12(2):42-9. Persian.

101. Tabrizizadeh M, Yasini Ardakani SM, Rostamzade P,Zare M. [The mental health status of students of medicine and dentistry; A study in Shahid Sadoughi University of Medical Sciences, Yazd, Iran]. Stride Dev Med Edu. 2012;9(2):153-61. Persian.

102. Simin H, Zahra G. A survey Beck test in university students \& its relationship between some related risk factors. Procedia Soc Behav Sci. 2011;28:558-62. doi:10.1016/j.sbspro.2011.11.107.

103. Mohd Kosnin AB, Ghaedi L. Prevalence of depression among un dergraduate students: gender and age differences. Int J Psychol Res. 2014;7(2):38-50. doi: 10.21500/20112084.657.

104. Tavakolizadeh J, Atarodi A, Ahmadpour S, Pourgheisar A. The prevalence of excessive mobile phone use and its relation with mental health status and demographic factors among the students of Gonabad University of Medical Sciences in 2011-2012. Razavi Int J Med. 2014;2(1). e15527. doi: 10.5812/rijm.15527.

105. Yousefi F, Mohamadkhani M. [Investigation of studentsâ mental health at Kurdistan University of Medical Science and it related with age, gender and their academic courses]. Med J Mashhad Univ Med Sci. 2014;56(6):354-61. Persian.

106. Bahrami M, Dehdashti A, Karami M. [Investigation depression prevalence and related effective factors amongstudents at health faculty Semnan University of Medical Sciences in 2017, Iran]. Zanko Med Sci. 2017;18(58):24-32. Persian.

107. Mohebian M, Dadashi M, Motamed N, Safdarian E. [Evaluation of depression, anxiety, stress levels and stressors among dental students of Zanjan University of Medical Sciences in academic year of 2015-2016]. J Med Educ Dev. 2017;10(26):60-71. Persian. doi:10.29252/edcj.10.26.60.
108. Lei XY, Xiao LM, Liu YN, Li YM. Prevalence of depression among chinese university students: A meta-analysis. PLoS One. 2016;11(4) e0153454. doi: 10.1371/journal.pone.0153454. [PubMed: 27070790] [PubMed Central: PMC4829172].

109. Puthran R, Zhang MW, Tam WW, Ho RC. Prevalence of depression amongst medical students: A meta-analysis. Med Educ. 2016;50(4):456-68. doi: 10.1111/medu.12962. [PubMed: 26995484].

110. Rotenstein LS, Ramos MA, Torre M, Segal JB, Peluso MJ, Guille C, et al. Prevalence of depression, depressive symptoms, and suicidal ideation among medical students: A systematic review and metaanalysis. JAMA. 2016;316(21):2214-36. doi: 10.1001/jama.2016.17324. [PubMed: 27923088]. [PubMed Central: PMC5613659].

111. Yen S, Robins CJ, Lin N. A cross-cultural comparison of depressive symptom manifestation: China and the United States. J Consult Clin Psychol. 2000;68(6):993-9. doi: 10.1037||0022-006x.68.6.993. [PubMed: 11142551].

112. Schaakxs R, Comijs HC, van der Mast RC, Schoevers RA, Beekman ATF, Penninx B. Risk factors for depression: Differential across age? Am J Geriatr Psychiatry. 2017;25(9):966-77. doi: 10.1016/j.jagp.2017.04.004. [PubMed: 28529007].

113. Bayram N, Bilgel N. The prevalence and socio-demographic correlations of depression, anxiety and stress among a group of university students. Soc Psychiatry Psychiatr Epidemiol. 2008;43(8):667-72. doi: 10.1007/s00127-008-0345-x. [PubMed: 18398558].

114. Bostanci M, Ozdel O, Oguzhanoglu NK, Ozdel L, Ergin A, Ergin N, et al. Depressive symptomatology among university students in Denizli, Turkey: Prevalence and sociodemographic correlates. Croat Med J. 2005;46(1):96-100. [PubMed: 15726682].

115. Grant K, Marsh P, Syniar G, Williams M, Addlesperger E, Kinzler $\mathrm{MH}$, et al. Gender differences in rates of depression among undergraduates: Measurement matters. J Adolesc. 2002;25(6):613-7. doi: 10.1006/jado.2002.0508. [PubMed: 12490179].

116. Wade TJ, Cairney J, Pevalin DJ. Emergence of gender differences in depression during adolescence: national panel results from three countries. J Am Acad Child Adolesc Psychiatry. 2002;41(2):190-8. doi: 10.1097/00004583-200202000-00013. [PubMed: 11837409].

117. Akechi T, Okamura H, Nakano T, Akizuki N, Okamura M, Shimizu $\mathrm{K}$, et al. Gender differences in factors associated with suicidal ideation in major depression among cancer patients. Psychooncology. 2010;19(4):384-9. doi: 10.1002/pon.1587. [PubMed: 19472294].

118. Moller-Leimkuhler AM, Bottlender R, Strauss A, Rutz W. Is there evidence for a male depressive syndrome in inpatients with major depression? J Affect Disord. 2004;80(1):87-93. doi: 10.1016/S01650327(03)00051-X. [PubMed: 15094262].

119. Li M, Huang F. The relationship between marital status, cohort, and depression symptoms in Taiwan. Innovation in Aging. 2019;3(Suppl 1):S311-2. doi: 10.1093/geroni/igz038.1140.

120. Bulloch AGM, Williams JVA, Lavorato DH, Patten SB. The depression and marital status relationship is modified by both age and gender. J Affect Disord. 2017;223:65-8. doi: 10.1016/j.jad.2017.06.007. [PubMed: 28732242].

121. Wu J, Wu YT, Feng SX, Meng H, Chen H. [Mediating effects on depression regarding the relationship between negative life events and suicide ideation among college students]. Zhonghua Liu Xing Bing Xue Za Zhi. 2012;33(11):1111-4. Chinese. [PubMed: 23290892].

122. Lipson SK, Lattie EG, Eisenberg D. Increased rates of mental health service utilization by U.S. college students: 10-year populationlevel trends (2007-2017). Psychiatr Serv. 2019;70(1):60-3. doi: 10.1176/appi.ps.201800332. [PubMed: 30394183]. [PubMed Central: PMC6408297]. 
Table 1. The Characteristics of the Studies Included in the Meta-analysis

\begin{tabular}{|c|c|c|c|c|c|c|c|}
\hline Study & Study Design & Study Location & $\begin{array}{l}\text { Total Sample } \\
\text { Size (N) }\end{array}$ & $\begin{array}{l}\text { Age (Mean } \pm \\
\text { SD) }\end{array}$ & Questionnaire & $\begin{array}{l}\text { Quality Scores } \\
\text { (NOS) }\end{array}$ & $\begin{array}{c}\text { Prevalence of } \\
\text { Depression (\%) }\end{array}$ \\
\hline Ahmadi (20) & Cross-sectional & Ahvaz & 200 & NA & $\begin{array}{l}\text { Beck Depression } \\
\text { Inventory [Beck } \\
\text { (II)] }\end{array}$ & 6 & 45.0 \\
\hline Molavi et al. (21) & Cross-sectional & Ardabil & 269 & NA & $\operatorname{Beck}(\mathrm{II})$ & 5 & 57.6 \\
\hline $\begin{array}{l}\text { Hashemi and } \\
\text { Kamkar (22) }\end{array}$ & Cross-sectional & Yasuoj & 421 & NA & $\operatorname{Beck}(\mathrm{II})$ & 5 & 69.1 \\
\hline Fakhari (23) & Cross-sectional & Tabriz & 600 & NA & Beck (II) & 5 & 42.0 \\
\hline $\begin{array}{l}\text { Yousefnazari } \\
(24)\end{array}$ & Cross-sectional & Tehran & 402 & $\mathrm{NA}$ & $\begin{array}{l}\text { Beck Depression } \\
\text { Inventory [Beck } \\
\text { (I)] }\end{array}$ & 5 & 99.9 \\
\hline $\begin{array}{l}\text { Musarezaie et } \\
\text { al. (25) }\end{array}$ & Cross-sectional & Isfahan & 715 & NA & Beck(II) & 6 & 44.1 \\
\hline $\begin{array}{l}\text { Ildarabady et } \\
\text { al. (27) }\end{array}$ & Cross-sectional & Zabul & 157 & NA & $\operatorname{Beck}(\mathrm{II})$ & 7 & 64.3 \\
\hline Karami (28) & Cross-sectional & Kashan & 208 & $\mathrm{NA}$ & Beck (II) & 5 & 50.0 \\
\hline Rezaei et al. (29) & Cross-sectional & Hamadan & 222 & $21.87 \pm 1.95$ & $\operatorname{Beck}(\mathrm{II})$ & 6 & 54.5 \\
\hline $\begin{array}{l}\text { Najafi Kalyani } \\
\text { et al. (30) }\end{array}$ & Cross-sectional & Fasa & 179 & NA & $\begin{array}{c}\text { Depression } \\
\text { anxiety stress } \\
\text { scale (DASS-21) }\end{array}$ & 5 & 53.1 \\
\hline Amani et al. (31) & Cross-sectional & Ardabil & 324 & $20.80 \pm 1.58$ & Beck (II) & 5 & 57.4 \\
\hline $\begin{array}{l}\text { Hasanzadeh et } \\
\text { al. (32) }\end{array}$ & Cross-sectional & Birjand & 231 & NA & Beck(II) & 6 & 12.1 \\
\hline $\begin{array}{l}\text { Dadkhah et al. } \\
\text { (33) }\end{array}$ & Cross-sectional & Ardabil & 409 & $20.03 \pm 1.20$ & $\operatorname{Beck}(\mathrm{II})$ & 5 & 49.9 \\
\hline $\begin{array}{l}\text { Khoshkhati et } \\
\text { al. (34) }\end{array}$ & Cross-sectional & Zanjan & 31 & NA & $\operatorname{Beck}(\mathrm{II})$ & 6 & 32.3 \\
\hline $\begin{array}{l}\text { Ahmari Tehran } \\
\text { et al. (35) }\end{array}$ & Cross-sectional & Ghom & 250 & $21.42 \pm 2.75$ & Beck (II) & 5 & 55.2 \\
\hline $\begin{array}{l}\text { Abedini et al. } \\
\text { (36) }\end{array}$ & Cross-sectional & Bandarabbas & 190 & NA & Beck (II) & 6 & 54.7 \\
\hline $\begin{array}{l}\text { Najafipour and } \\
\text { Yektatalab (37) }\end{array}$ & Cross-sectional & Jahrom & 150 & NA & $\operatorname{Beck}(\mathrm{II})$ & 6 & 36.0 \\
\hline $\begin{array}{l}\text { Zamanian Z et } \\
\text { al. (38) }\end{array}$ & Cross-sectional & Shiraz & 358 & $20.71 \pm 2.07$ & $\operatorname{Beck}(\mathrm{II})$ & 5 & 45.3 \\
\hline $\begin{array}{l}\text { Azarniveh and } \\
\text { Tavakoli } \\
\text { Khomizi (39) }\end{array}$ & Cross-sectional & Zabul & 375 & $21.85 \pm 3.49$ & $\operatorname{Beck}(\mathrm{II})$ & 5 & 44.8 \\
\hline $\begin{array}{l}\text { Rahmani } \\
\text { Bidokhti et al. } \\
(40)\end{array}$ & Cross-sectional & Birjand & 151 & $22 \pm 2$ & $\operatorname{Beck}(\mathrm{I})$ & 5 & 31.8 \\
\hline Foroutani (41) & Cross-sectional & Larestan & 134 & NA & $\operatorname{Beck}(\mathrm{II})$ & 6 & 42.5 \\
\hline $\begin{array}{l}\text { Tavakolizadeh } \\
\text { and Moham- } \\
\text { madpour } \\
(42)\end{array}$ & Cross-sectional & Gonabad & 291 & NA & Beck(II) & 6 & 62.5 \\
\hline
\end{tabular}




\begin{tabular}{|c|c|c|c|c|c|c|c|}
\hline $\begin{array}{l}\text { Hashemi } \\
\text { Mohamm } \\
\text { adabad et al. } \\
\text { (43) }\end{array}$ & Cross-sectional & Yasuoj & 452 & NA & Beck (II) & 5 & 61.9 \\
\hline Rafati et al. (44) & Cross-sectional & Jiroft & 173 & $21.30 \pm 1.90$ & Beck (II) & 5 & 59.0 \\
\hline $\begin{array}{l}\text { Mohtashamipour } \\
\text { et al. ( } 45 \text { ) }\end{array}$ & Cross-sectional & Mashhad & 256 & NA & Beck (II) & 5 & 45.3 \\
\hline $\begin{array}{l}\text { Behdani et al. } \\
(46)\end{array}$ & Cross-sectional & Sabzevar & 264 & $21.56 \pm 2.65$ & Beck (II) & 6 & 75.4 \\
\hline $\begin{array}{l}\text { Oskouei and } \\
\text { Kahkeshan (47) }\end{array}$ & Cross-sectional & Tehran & 393 & NA & Beck (II) & 5 & 36.1 \\
\hline $\begin{array}{l}\text { Mokhtari et al. } \\
(48)\end{array}$ & Cross-sectional & West Azerbaijan & 3859 & NA & $\begin{array}{c}\text { General Health } \\
\text { Questionnaire } \\
\text { (GHQ-28) }\end{array}$ & 5 & 8.5 \\
\hline $\begin{array}{l}\text { Aghakhani et } \\
\text { al. (49) }\end{array}$ & Cross-sectional & Urmia & 628 & $22 \pm 0.30$ & Beck (II) & 7 & 52.5 \\
\hline $\begin{array}{l}\text { Mohammadzadeh } \\
\text { (50) }\end{array}$ & Cross-sectional & Ilam & 381 & $21 \pm 0.99$ & Beck (II) & 5 & 76.4 \\
\hline $\begin{array}{l}\text { Jalilian et al. } \\
\text { (51) }\end{array}$ & Cross-sectional & Hamadan & 235 & NA & $\operatorname{Beck}(\mathrm{II})$ & 6 & 37.0 \\
\hline $\begin{array}{l}\text { Parvaresh et al. } \\
\text { (52) }\end{array}$ & Cross-sectional & Kerman & 414 & NA & Beck (II) & 7 & 24.4 \\
\hline Eslami et al. (53) & Cross-sectional & Jahrom & 356 & NA & Beck (II) & 5 & 39.0 \\
\hline $\begin{array}{l}\text { Eslami et al. } \\
(54)\end{array}$ & Cross-sectional & Gorgan & 193 & NA & Beck (II) & 5 & 45.1 \\
\hline Sharifi et al. (55) & Cross-sectional & Kashan & 307 & NA & $\operatorname{Beck}(\mathrm{I})$ & 6 & 35.8 \\
\hline $\begin{array}{l}\text { Dehdari et al. } \\
\text { (56) }\end{array}$ & Cross-sectional & Tehran & 222 & $23 \pm 3.60$ & DASS-21 & 6 & 59.5 \\
\hline Azizi et al. (57) & Cross-sectional & Tehran & 130 & NA & Beck(II) & 5 & 52.3 \\
\hline $\begin{array}{l}\text { Baghiani et al. } \\
(58)\end{array}$ & Cross-sectional & Yazd & 125 & NA & Beck(II) & 6 & 42.4 \\
\hline $\begin{array}{l}\text { Rahnamay } \\
\text { Namin (59) }\end{array}$ & Cross-sectional & $\begin{array}{l}\text { Takestan, Abhar } \\
\text { and } \\
\text { Booyinalzahra }\end{array}$ & 407 & NA & Beck (II) & 6 & 65.8 \\
\hline $\begin{array}{l}\text { Ghasemnegad } \\
\text { and } \\
\text { Barchordary } \\
(60)\end{array}$ & Cross-sectional & $\begin{array}{l}\text { Gilan and } \\
\text { Lahijan }\end{array}$ & 150 & NA & Beck (II) & 7 & 48.0 \\
\hline Masoudi Asl (61) & Cross-sectional & Yasuoj & 200 & NA & Beck (II) & 5 & 49.0 \\
\hline $\begin{array}{l}\text { Mogharab et al. } \\
(62)\end{array}$ & Cross-sectional & Birjand & 400 & $22 \pm 3$ & Beck(II) & 6 & 45.0 \\
\hline $\begin{array}{l}\text { Nourouzi } \\
\text { Eghdam (63) }\end{array}$ & Cross-sectional & Miyaneh & 318 & $\mathrm{NA}$ & Beck(II) & 5 & 66.0 \\
\hline Sam et al. (64) & Cross-sectional & Kerman & 376 & $20.20 \pm 2.20$ & Beck(II) & 5 & 46.0 \\
\hline $\begin{array}{l}\text { Mazahari et al. } \\
(65)\end{array}$ & Cross-sectional & Rafsanjan & 310 & $20.57 \pm 1.56$ & Beck (II) & 6 & 37.1 \\
\hline Safari et al. (66) & Cross-sectional & Kermanshah & 356 & $20.73 \pm 2.63$ & DASS-21 & 5 & 69.7 \\
\hline $\begin{array}{l}\text { Ghorban } \\
\text { Alizadeh } \\
\text { Ghaziyani et al. } \\
\text { (67) }\end{array}$ & Cross-sectional & Multiple & 180 & NA & Beck(II) & 5 & 67.8 \\
\hline $\begin{array}{l}\text { Rashidi Zaviyeh } \\
(68)\end{array}$ & Cross-sectional & Zanjan & 148 & $\mathrm{NA}$ & Beck(II) & 5 & 50.0 \\
\hline Miri et al. (69) & Cross-sectional & Birjand & 390 & NA & Beck (II) & 5 & 57.4 \\
\hline $\begin{array}{l}\text { Jazayeri and } \\
\text { Ghahari }(70)\end{array}$ & Cross-sectional & Tankabon & 120 & NA & Beck (II) & 6 & 29.2 \\
\hline
\end{tabular}




\begin{tabular}{|c|c|c|c|c|c|c|c|}
\hline $\begin{array}{l}\text { Salmani } \\
\text { Barough et al. } \\
\text { (71) }\end{array}$ & Cross-sectional & Tehran & 67 & NA & Beck(II) & 5 & 26.9 \\
\hline $\begin{array}{l}\text { Foroughan et } \\
\text { al. }(72)\end{array}$ & Cross-sectional & Bandarabbas & 271 & NA & Beck (II) & 6 & 43.9 \\
\hline $\begin{array}{l}\text { Rezaei Adaryani } \\
\text { et al. (73) }\end{array}$ & Cross-sectional & Tehran & 223 & $25.30 \pm 2.68$ & DASS-21 & 6 & 51.6 \\
\hline Rafati et al. (74) & Cross-sectional & Shiraz & 307 & NA & Beck (II) & 6 & 59.9 \\
\hline $\begin{array}{l}\text { Rezayat and } \\
\text { Dehgannayeri } \\
\text { (75) }\end{array}$ & Cross-sectional & Tehran & 249 & NA & $\operatorname{Beck}(\mathrm{II})$ & 6 & 38.6 \\
\hline $\begin{array}{l}\text { Mehri and } \\
\text { Sadighi } \\
\text { Soumeh } \\
\text { Kouchak (76) }\end{array}$ & Cross-sectional & Sabzevar & 270 & $23.42 \pm 3.63$ & GHQ-28 & 6 & 23.7 \\
\hline $\begin{array}{l}\text { Basati MA et al. } \\
\text { (77) }\end{array}$ & Cross-sectional & Kermanshah & 260 & NA & DASS-21 & 6 & 26.9 \\
\hline $\begin{array}{l}\text { Bahrami et al. } \\
(78)\end{array}$ & Cross-sectional & Isfahan & 300 & NA & GHQ-28 & 5 & 22.3 \\
\hline $\begin{array}{l}\text { Mortazavi } \\
\text { Tabatabaei et } \\
\text { al. (79) }\end{array}$ & Cross-sectional & Tehran & 390 & NA & Beck(II) & 5 & 49.7 \\
\hline $\begin{array}{l}\text { Maleki et al. } \\
(80)\end{array}$ & Cross-sectional & Hamadan & 1191 & NA & $\operatorname{Beck}(\mathrm{II})$ & 5 & 27.1 \\
\hline $\begin{array}{l}\text { Babadi-Akashe } \\
\text { et al. ( } 81)\end{array}$ & Cross-sectional & Shahrekord & 296 & NA & $\begin{array}{c}\text { Symptom } \\
\text { Checklist } \\
\text { 90-Revised } \\
(\text { SCL-90-R) }\end{array}$ & 5 & 17.2 \\
\hline $\begin{array}{l}\text { Mousavi et al. } \\
(82)\end{array}$ & Cross-sectional & Tehran & 205 & $24.70 \pm 1.69$ & GHQ-28 & 7 & 25.4 \\
\hline $\begin{array}{l}\text { EyvanBaga et al. } \\
\text { (83) }\end{array}$ & Cross-sectional & Khalkhal & 202 & NA & $\operatorname{Beck}(\mathrm{II})$ & 7 & 21.8 \\
\hline Faraji et al. (84) & Cross-sectional & Ardabil & 300 & NA & $\operatorname{Beck}(\mathrm{II})$ & 6 & 57.7 \\
\hline Golzar et al. (85) & Cross-sectional & Shiraz & 200 & $21.66 \pm 11.20$ & $\operatorname{Beck}(\mathrm{II})$ & 6 & 64.0 \\
\hline $\begin{array}{l}\text { Hosanei et al. } \\
(86)\end{array}$ & Cross-sectional & Mazandaran & 285 & NA & GHQ-28 & 5 & 89.8 \\
\hline $\begin{array}{l}\text { Khushde et al. } \\
\text { (87) }\end{array}$ & Cross-sectional & $\begin{array}{c}\text { Sistan and } \\
\text { Baluchestan }\end{array}$ & 204 & NA & Beck(II) & 7 & 93.1 \\
\hline $\begin{array}{l}\text { Mousavi et al. } \\
\text { (88) }\end{array}$ & Cross-sectional & Isfahan & 435 & $21.78 \pm 2.33$ & Beck (II) & 7 & 28.0 \\
\hline $\begin{array}{l}\text { Ajilchi and } \\
\text { Nejati (89) }\end{array}$ & Cross-sectional & Tehran & 122 & NA & DASS-21 & 5 & 24.6 \\
\hline $\begin{array}{l}\text { Poorolajal et al. } \\
(90)\end{array}$ & Cross-sectional & Hamadan & 1259 & NA & GHQ-28 & 7 & 24.1 \\
\hline Jafari et al. (91) & Cross-sectional & Shiraz & 477 & NA & DASS-21 & 7 & 35.6 \\
\hline $\begin{array}{l}\text { Jamshidi et al. } \\
(92)\end{array}$ & Cross-sectional & Ahvaz & 781 & NA & GHQ-28 & 7 & 11.7 \\
\hline $\begin{array}{l}\text { Hashemi } \\
\text { Mohammad } \\
\text { Abad et al. (93) }\end{array}$ & Cross-sectional & Yasuoj & 464 & NA & Beck (II) & 5 & 63.8 \\
\hline Talaei et al. (94) & Cross-sectional & Mashhad & 1200 & NA & Beck (II) & 6 & 32.2 \\
\hline Imani et al. (95) & Cross-sectional & Hormozgan & 95 & $21.12 \pm 1.44$ & GHQ-28 & 5 & 17.9 \\
\hline $\begin{array}{l}\text { Parvizrad et al. } \\
\text { (96) }\end{array}$ & Cross-sectional & Mazandaran & 334 & NA & GHQ-28 & 6 & 47.9 \\
\hline Safiri et al. (97) & Cross-sectional & Tabriz & 175 & NA & $\operatorname{Beck}(\mathrm{I})$ & 8 & 78.3 \\
\hline $\begin{array}{l}\text { Zolfaghari et al. } \\
(98)\end{array}$ & Cross-sectional & Toyserkan & 400 & $\mathrm{NA}$ & SCL-90-R & 5 & 72 \\
\hline
\end{tabular}




\begin{tabular}{|c|c|c|c|c|c|c|c|}
\hline $\begin{array}{l}\text { Hadavi et al. } \\
\text { (99) }\end{array}$ & Cross-sectional & Rafsanjan & 250 & $19.92 \pm 1.66$ & SCL-90-R & 5 & 23.6 \\
\hline $\begin{array}{l}\text { Jahani hashemi } \\
\text { et al. (100) }\end{array}$ & Cross-sectional & Qazvin & 314 & NA & SCL-90-R & 6 & 75.2 \\
\hline $\begin{array}{l}\text { Jahani hashemi } \\
\text { et al. (100) }\end{array}$ & Cross-sectional & Qazvin & 293 & NA & SCL-90-R & 6 & 67.9 \\
\hline $\begin{array}{l}\text { Tabrizizadeh et } \\
\text { al. (101) }\end{array}$ & Cross-sectional & Yazd & 191 & NA & SCL-90-R & 6 & 39.3 \\
\hline $\begin{array}{l}\text { Hojjatoleslami } \\
\text { and Ghodsi } \\
(102)\end{array}$ & Cross-sectional & Hamadan & 280 & $22 \pm 3.5$ & Beck(II) & 6 & 73.6 \\
\hline $\begin{array}{l}\text { Ghaedi and } \\
\text { MohdKosnin } \\
\text { (103) }\end{array}$ & Cross-sectional & Isfahan & 400 & $21.45 \pm 1.66$ & Beck(II) & 5 & 40.0 \\
\hline $\begin{array}{l}\text { Tavakolizadeh } \\
\text { et al. (104) }\end{array}$ & Cross-sectional & Gonabad & 700 & NA & GHQ-28 & 6 & 29.7 \\
\hline $\begin{array}{l}\text { Yousefi and Mo- } \\
\text { hamadkhani } \\
(105)\end{array}$ & Cross-sectional & Sanandaj & 1000 & NA & GHQ-28 & 6 & 99.4 \\
\hline $\begin{array}{l}\text { Bahrami et al. } \\
(106)\end{array}$ & Cross-sectional & Semnan & 177 & $22.15 \pm 3.88$ & Beck (II) & 7 & 80.2 \\
\hline $\begin{array}{l}\text { Mohebian et al. } \\
\text { (107) }\end{array}$ & Cross-sectional & Zanjan & 149 & $21.7 \pm 2.28$ & DASS-21 & 6 & 31.5 \\
\hline $\begin{array}{l}\text { Hadavi and } \\
\text { Rostami (3) }\end{array}$ & Cross-sectional & Rafsanjan & 400 & $20.78 \pm 2.37$ & Beck (II) & 6 & 50.7 \\
\hline
\end{tabular}

Abbreviation: NA, not available. 